Draft submission for review to CSIRO PUBLISHING

\title{
Variability of optimum sowing time for wheat yield in Western
}

\section{Australia}

DL Sharma $^{\mathrm{AF}}$, MF D’Antuono ${ }^{\mathrm{B}}$, WK Anderson ${ }^{\mathrm{C}}$, BJ Shackley ${ }^{\mathrm{D}}, \mathrm{CM}$ Zaicou-Kunesch ${ }^{\mathrm{E}}$, and M Amjad ${ }^{\mathrm{A}}$

$10{ }^{\mathrm{A}}$ Centre for Cropping Systems, Department of Agriculture and Food, Lot 12 York Rd, Northam, W A 6401, Australia;

${ }^{\mathrm{B}}$ Department of Agriculture and Food, 3 Baron-Hay Court, South Perth, WA 6151, Australia;

${ }^{\mathrm{C}}$ Department of Agriculture and Food, 444 Albany Highway, Albany, W A 6330,

15 Australia; and School of Plant Biology, The University of Western Australia, 35 Stirling Highway, Crawley, WA 6009 Australia;

${ }^{\mathrm{D}}$ Department of Agriculture and Food, 10 Dore St, Katanning, WA 6317, Australia;

${ }^{\mathrm{E}}$ Department of Agriculture and Food, 20 Gregory St, Geraldton, WA 6530, Australia;

${ }^{\mathrm{F}}$ Corresponding author: dsharma@agric.wa.gov.au

20

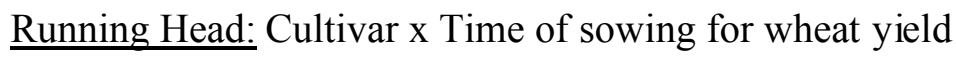




\section{Abstract}

Sowing wheat (Triticum aestivum L.) at the right time is one of the most important means of maximising grain yield in dryland agriculture. Objectives of this study were to 5 understand the variation in estimates of optimum sowing time as influenced by cultivar and environmental characteristics, and to assess the relative importance of location, season, sowing time and cultivar factors in maximising grain yield in Western Australia. Twenty seven cultivar $\mathrm{x}$ time of sowing experiments were conducted over three seasons (2003-05) at a range of locations (annual rainfall $300-450 \mathrm{~mm}$, latitudes $28-35^{0} \mathrm{~S}$ ).

10 There were four types of cultivar x sowing time responses, namely, quadratic, linear declining, flat and linear increasing, associated with opening rains before mid-May, opening rains after mid-May, low yielding sites and good spring rains, respectively.

Regression tree analysis revealed that differences among cultivars in Tmax (sowing time when maximum grain yield was achieved) were much less in the eastern sites

15 (mostly drier seasons). A biplot differentiated cultivars for Tmax across the range of environments used while the subset regression analysis specifically indicated an association of average temperature and growing season rainfall with variation for Tmax of individual cultivars.

The yield penalty for sowing before the optimum time in quadratic type responses was

20 clearly greater for shorter season cultivars but no clear relationship was apparent between maturity class of cultivars and the penalty for late sowing, possibly due to differential plasticity of cultivars for grain weight under harsh finishing conditions. The duration of the optimum sowing window at a given location was inversely proportional to the yield potential implying that it is critical to sow at or close to the optimum time when the yield 
potential is high, most common when the season breaks early. Yield component analysis showed that the relative change in grain yield over sowing dates was significantly correlated to relative changes in grain numbers $/ \mathrm{m}^{2}$ in the late May sowings but other yield components were also important in the early May experiments. Sowing time

5 accounted for $10 \%$ of grain yield variation as compared to cultivar (1\%) while the rest was due to uncontrollable factors of location and season. 


\section{Introduction}

Very early in the process of adaptation of the wheat crop to rainfed conditions in Australia it was understood that the responses of wheat cultivars to the environment were critical for maximising grain yield (Farrer 1898). However, the question of the optimum

5 sowing time for the wheat crop was complicated more by the need in the pre-herbicide era to control weeds before sowing and to conserve soil water by fallowing, than by the timing of the opening rains. The optimum sowing time (sometimes referred to as the 'sowing window') to maximise grain yield was later defined as the period which resulted in the crop flowering after the danger of frost damage had passed but before the period

10 available for grain growth was shortened by the onset of summer drought (Single 1961; Fischer and Kohn 1966; Syme 1968). Researchers have attempted to understand and manipulate the vernalisation and photoperiod responses of Australian wheat cultivars as one means of adjusting the flowering time to fit the seasonal temperature and rainfall pattern in various environments (Gott 1961; Pugsley 1965; Syme 1968; French et al

15 1979; Angus et al 1981; Crofts et al 1984; Davidson et al 1985). Partly as the result of the research across Australia, the average sowing date of the wheat crop in the $1980 \mathrm{~s}$ advanced by about 10 days with a greater shift of $2-3$ weeks in Western Australia and Queensland (Stephens and Lyons 1998).

Research to ascertain the optimum sowing time for wheat has been conducted in all the

20 major cropping areas of Australia. Most of the experiments in these studies had excellent weed control obtained through previous fallow, hand weeding or herbicides, and diseases were controlled with fungicides where required. The major reports and their findings are summarised in Table 1. Differences in the estimates of the optimum sowing time in the 
literature appear to be related to maturity types of the cultivars used, the actual sowing times and the seasonal conditions. In general, the higher rates of yield decline after the optimum sowing time in all the experiments described above were associated with either higher levels of yield (4-6 t/ha, Woodruff and Tonks 1983; Doyle and Marcellos 1974), 5 or stressful grain filling periods (low rainfall after anthesis), or warmer environments with shorter growing seasons (central Queensland, northern Western Australia). There are often interactions between sowing times and other agronomic practices such as response to nitrogen (N) fertilizers (Mason et al 1978), seed rate and $N$ (Anderson 1992) and tillage methods (Schmidt and Belford 1993). The interaction of sowing time with the

10 phenological responses of cultivars has been clearly shown in many of the studies quoted with long season cultivars most often giving their highest yields at the earlier sowings, although not necessarily out-yielding the early or the mid season types. Variations in the timing of the opening rains and in the possible responses of cultivars to sowing time make it desirable to understand the characteristics of both cultivars and seasons that are associated with changes in the optimum sowing time so that farmers can maximise yields and profits in any given situation.

[Table 1 near here]

Sowing at the time when grain yields are likely to be greatest is a relatively cheap way to improve farm profits. However, the optimum sowing time is not a fixed time but seems 20 to vary with location, season, cultivar and possibly other factors. Most of the responses reported in Table 1 comprise only genotype $\mathrm{x}$ sowing time interactions often involving very few cultivars and thus excluding the opportunity of investigating other important interactions that would be available in a bigger genotype $\mathrm{x}$ environment $\mathrm{x}$ sowing time 
matrix involving many cultivars and environments. Understanding of the sources of this variability can possibly assist farmers with decisions about sowing strategies within seasons and the choice of cultivars. Further, the optimum sowing time has often been taken as the average of experiments over a number of sites and seasons. This method can

5 bias the result towards the higher-yielding experiments and may ignore the range of seasonal variation. It appears that responding to such variation in the optimum sowing time can be a useful addition to management decisions. Modern statistical techniques such as smoothing splines have the capacity to provide more precise and accurate estimates of the optimum sowing date range, independent of the actual sowing dates.

10 Data for dryland wheat derived from average farm yields and field experiments using historical cultivars in several countries have shown that the proportion of yield improvement attributable to management overall was much greater compared to genotype (Byerlee 1994). Analysis of two factorial experiments with a small number of wheat cultivars in Western Australia also has indicated that variations in environments (seasons

$15 \mathrm{x}$ locations) and interactions between environments and management (seed rate, sowing time and $\mathrm{N}$ fertilizer) account for about $70 \%$ of yield variation (Anderson et al 2005). The relative importance of sowing at the appropriate time has been recognised from regional farm data in South Australia where the proportion of variation in grain yield due to sowing date has ranged from 30 to $68 \%$ depending on rainfall zone (RJ French quoted in

20 Donald and Puckridge 1975). However, such data from controlled experiments comparing the impact on grain yield of sowing time compared to other management variables are much less evident.

The aims of the field experiments described in this paper are:- 
1. To assess the influence of cultivar and environment on estimates of the optimum sowing time for maximum yield for wheat,

2. To assess the characteristics of wheat cultivars that are related to any differences in their response to sowing time, and

3. To assess the relative importance of sowing time, cultivar, location and season in yield variation of wheat in Western Australia. 


\section{Methods and Materials}

Sites, experimental materials and basal treatments

Twenty-seven 'cultivar by time of sowing' field experiments were conducted over 5 three years (2003-2005) at 15 sites in the major agro-ecological zones of Western Australia (Table 2). Each experiment had a core set of 9 cultivars and 15 new cultivars chosen from available cultivars/crossbreds according to their suitability for different agro-ecological situations as suggested by their breeders. Maturity classes of the nine core cultivars were: long (Calingiri, Spear), medium-long (EGA Eagle Rock), medium

10 (Carnamah, GBA Ruby), short-medium (Wyalkatchem, EGA Bonnie Rock) and short (Westonia, Tammarin Rock). There were 2 or 3 sowing dates with the first date sown as close as possible to the opening rains (within 7days) and subsequent sowings at 2-3 week intervals.

All experiments were sown using a cone seeder with either 7 or 8 rows at 22 or $18 \mathrm{~cm}$

15 spacings and plot length of $20 \mathrm{~m}$. Where possible, seed was sourced from a common location each year. Seeding rate was adjusted to a target of 150 plants $/ \mathrm{m}^{2}$ using germination tests and kernel weights and all experiments were sown into good soil Standard crop management practices including weed and disease and pest control and non-limiting fertiliser practices were used.

\section{Measurements}

Soils varied from deep sand to heavy clay loam as assessed by hand texturing (Schoknecht 2002). Plant available water was estimated for each site by reference to soil

25 texture as described in Moore et al (1998). Climatic data were obtained from weather 
stations of the Department of Agriculture and Food or the Australian Bureau of Meteorology close to each site. In general, locations in southern latitudes were cooler and evaporation lower than locations in the northern latitudes and the eastern, low rainfall locations. The length of the growing season is typically shorter in the north compared to 5 the south (about $4 \mathrm{cf} 6$ months).

Grain yield was measured after mechanical harvesting of $18 \mathrm{~m}$ from each plot. Yield components were measured from two, $1 \mathrm{~m}$ long rows in each plot. The samples were weighed and number of heads determined. Each sample was then threshed using a single plant thresher. A subsample of approximately 400 grains was counted and weighed to

10 estimate the average kernel weight from each plot. The number of kernels per head, kernel weight, and number of kernels per unit area were then calculated using these data. The number of green tillers was counted from two, $1 \mathrm{~m}$ long rows in each plot at 50-65 days from sowing and used as an estimate of maximum tiller number.

\section{Statistical analyses}

All experiments had three replications using a split plot design with sowing dates as main plots and cultivars as sub-plots. Sowing times were latinised across and within banks. Each experiment was analysed separately for grain yield and yield components

20 using analysis of variance in GenStat ${ }^{\circledR}$ for Windows (2006). A further analysis of variance was conducted on the pooled data of grain yield that allowed estimation of the sources of variation in the Genotype $\mathrm{x}$ Environment $\mathrm{x}$ Time of sowing matrix.

In order to estimate the date of maximum grain (Tmax) yield a linear mixed model using the ASREML library (2006) in the R Statistical System ${ }^{\odot}$ (2006) was used to fit 
smoothing splines to the yield data for each cultivar in each trial. The day of the year corresponding to the estimated maximum yield for each cultivar within each experiment was estimated following Verbyla et al (1999). Experiments with only 2 dates of sowing were simply fitted using a straight line regression. Estimates of the inverse and 5 confidence limits were made using the method described in Verbyla et al (1999) as per the calibration example.

A regression tree analysis as described in Del Cima (2004) was done to identify the most important location factor associated with the quantum of Tmax variance among cultivars. Biplots were fitted using GenStat ${ }^{\circledR}$ Statistical program following Gabriel (1971)

10 to visualise the differences between cultivars and environments for Tmax. The vectors in the biplot were produced using centered means option only and were not standardised. A subset regression analysis $\left(\mathrm{GenStat}^{\circledR}\right)$ restricted to datasets from only 81 records ( 9 cultivars $\mathrm{x} 9$ experiments) that had quadratic responses and had their first sowing done in early May (day of year of first sowing 122-131), was conducted in order to determine the 15 environmental factors affecting variation in Tmax. Finally, a correlation analysis $\left(\right.$ GenStat $\left.^{\circledR}\right)$ of relative change in grain yield with relative changes in yield components (value of the lower-yielding sowing time relative to the highest-yielding sowing time) was used to indicate the importance of various components for changes in grain yield with sowing time. 


\section{Results and discussion}

Types of yield responses

5 There were four types of yield responses to sowing times (Figure 1): 1) a quadratic response where a distinct optimum sowing time could be observed; 2) a linear response where yield decreased after the first sowing; 3) a flat response where cultivars were unresponsive to sowing time; and, 4) a linear response where yields increased after the first sowing. Quadratic responses were usually associated with seasons where the opening

10 rains occurred before mid-May. Linear decreasing responses were usually associated with seasons when the opening rains came after mid-May. Flat responses were associated with dry seasons that broke late. This was rarely the dominant response at a particular site. The true rising response (increasing grain yield despite late break) were associated with experiments where the first sowing date experienced greater stress (cold, frost or dry

15 winter) than later sowing or when later sowing was still in a position to avail late rain opportunity.

[Figure 1 near here]

Quadratic and linear decreasing responses were most common amongst cultivars $(42 \%$ and $44 \%$, respectively). Linear increasing responses (about $9 \%$ ) and flat responses were

20 least common $(<1 \%)$. The remaining $4 \%$ were intermediate responses between declining and other types. Cultivar Calingiri had the most linear declining responses (52\%), Tammarin Rock had the most quadratic responses (52\%) and Wyalkatchem had the most linear increasing responses (17\%). 


\section{Topt and Tmax}

Cultivars differed for optimum sowing times (Topt) in many experiments. An example of cultivar differences in the optimum sowing time is given in Figure 2 for Avondale in

5 2005. In this experiment, cultivars Tammarin Rock and Wyalkatchem had a clearly visible Topt at day 143 (May 23) in contrast to cultivar Calingiri which had no clear optimum in this experiment. The point of highest yield in such cases is referred to as Tmax rather than Topt. It is anticipated however, that the Tmax points from many experiments would converge to their respective Topt values i.e. $\mathrm{E}[\mathrm{Tmax}]=$ Topt, where

$10 \mathrm{E}[$.$] denotes the expected value of a random variable.$

[Figure 2 near here]

\section{Cultivar effects on Tmax}

When a number of experiments in successive years at a single site were considered, in

15 some years there were no differences between cultivars and in other years at the same sites, the differences were large (Table 3).

[Table 3 near here]

In total, there were 10 experiments where cultivars did not differ for Tmax and all the cultivars had generally linear decreasing responses. All but one (Mukinbudin 2003) had

20 their first sowing date later than 23rd May (day 143). The practical implication of this is that matching the cultivar to the sowing time is less critical when the season breaks later in terms of differences in the relative yield expectation, as long as head emergence can escape frost or unless the moisture conditions in spring can be predicted with confidence. Furthermore, a regression tree analysis of the Tmax variances revealed that while the 
wetter sites (western longitudes) could have a lower or a higher variance, the drier sites (eastern longitudes) had only low levels of cultivar differentiation, if at all. The short dry seasons common in the lower rainfall areas probably compressed genetic differences.

The $\mathrm{G} \times \mathrm{E}$ interaction in response to sowing time is illustrated in Figure 3. The 5 responses of Calingiri and Tammarin Rock varied between Eradu in the north and Avondale, about $300 \mathrm{~km}$ further south. At the Eradu site, the optimum sowing date for Calingiri was about 20 days after the opening rains but there was no clear optimum date for sowing Tammarin Rock. In contrast, at the Avondale site, Tammarin Rock had a clear optimum about 20 days after the opening rain while Calingiri yielded most from sowing 10 close to the break of the season.

[Figure 3 near here]

A biplot for the nine core cultivars in the 23 trials where the first sowing was close to the break of the season, was used to visually examine the GxE interaction of Tmax estimates (Figure 4). Eighty five percent of the $\mathrm{G} \times \mathrm{E}$ sums of squares for Tmax was

15 explained using first and second principal components in this figure. Relative positioning of cultivar vectors on the biplot enabled grouping of cultivars for the GxE interactions. The inter-vector angles depicted cultivar grouping in which Calingiri and Tammarin Rock appeared at the two extremes. Examination of the data showed that this was largely due to the fact that Calingiri and Tammarin Rock were more variable in their rankings

20 across sites than the other cultivars. The lengths of vectors in the biplot indicate that cultivars such as Calingiri, Carnamah, EGA Bonnie Rock and Tammarin Rock (longer vectors) were relatively responsive to environments compared to cultivars such as 
Westonia and Wyalkatchem (shorter vectors), which were the least responsive cultivars to environmental changes, or were more widely adapted in respect to Tmax.

[Figure 4 near here]

5

Environmental effects on Tmax

The scatter of environments on the biplot (indicated by numbers and letters on Figure 4) implies that the cultivars differed in their response to the diverse environments used in the experiments as shown by the relative position of the sites with respect to cultivar vectors. For example, Carnamah and EGA Eagle Rock, two closely located cultivars on

10 the biplot, had very similar Tmax values in all experiments but cultivars Calingiri and Tammarin Rock, the two extreme cultivars on the biplot had diverse Tmax values (Table $3)$.

The relationship between Tmax and the environmental variables was investigated using subset regression with a range of possible explanatory variables, namely, estimated 15 available soil water, latitude, longitude, heatsums during winter months (May to July), heatsums during spring months (August to October), growing season rainfall from first sowing date, rainfall during winter months (May to July), rainfall during spring months (August to October), pre-season rainfall, date of first sowing, and maturity class of the cultivar. When Tmax for individual cultivars in the quadratic response group of sites $(9$

20 records per cultivar) was regressed against these variables, about two-thirds of the variation for most cultivars was accounted for by 2-3 terms (Table 4); the important ones being heatsum in the winter months, latitude, growing season rainfall and heatsum in the spring months. This analysis suggests that although the overall factors influencing 
response to sowing time might be similar, interactions of cultivars with these factors were distinct.

(Table 4 near here)

Average yield components at the highest yielding sowing times in 23 trials show that

5 the position of the top five cultivars on the biplot was related to the number of green tillers shown in Table 5. However, there were no clear relationships with the other yield components and the position of the cultivars on the biplot, indicating the complexity of the relationships between yield and yield components amonst the cultivars.

(Table 5 near here)

\section{$10 \quad$ Range of Tmax}

A quadratic yield response to sowing time implies that there can be penalties both for sowing some cultivars too early in seasons as well as for sowing too late. Given that sowing can not be completed on a single day (Tmax), a more practical approach is to use

15 a range of dates (sowing 'window') when the change to maximum yield is within an acceptable limit estimated for each location and cultivar. We have used a criterion of $10 \%$ yield variation from Tmax and named that period 'Ymax window'. Calculations revealed a spread of 10-20days for the estimates of Ymax window, close to the range of times that broad-acre farmers can achieve for sowing the crop using modern equipment. Further, as

20 surrogate for yield penalty rates (discussed later), it was observed that Tmax window was shorter in seasons when the site yield was greater (for example cultivar Calingiri at Mukinbudin as shown in Figure 5). This implies that early sowing in the Mediterranean type environments such as Western Australia is extremely important to build and sustain high yield potential. 
(Figure 5 near here)

\section{Yield penalty due to late sowing}

There were several factors influencing the rate of decline of grain yield (gyd) after the highest yielding sowing time in each experiment. The yield differences between cultivars

5 as well as gyd was greater in seasons when the yield was greater. The reverse applied in poorer seasons. An example is shown for the Mukinbudin site in 2003, 2004 and 2005 (Figure 6). The practical application of these observations is that choice of cultivars in seasons that break early and have a higher potential yield (greater spread of the data in 2003 as shown in Figure 6) are important for grain yield but less so in the average and

10 lower yielding seasons when the opening rains come later. In general the higher yielding seasons are associated more often with early rainfall, which in turn is associated with better responses to fertilizer applications (Anderson et al. 1997) and greater opportunity for pre-sowing weed control.

(Figure 6 near here)

15 There were no consistent effects of soil type or location within Western Australia on gyd in the datasets. It can only be assumed that any real effects of soil types and locations were obscured by seasonal influences. This result in respect of location is contrary to the data from previous published results (Shackley 2000 in Table 1 where the yield decline after the optimum sowing time was greater in the warmer, northern locations. The general expectation is that the short season cultivars would have a lower penalty for late sowing than the longer season cultivars irrespective of location. However, the proposition that varietal differences for gyd are a simple reflection of the maturity class could not be shown in our experiments. For example, the relative rates of yield decline of a long 
season cultivar (Calingiri), a medium season cultivar (Carnamah) and short season cultivar (Tammarin Rock) varied across sites and seasons in a way that was not apparently related to maturity class (Figure 7). The reasons for the differences between cultivars in gyd could be related to duration of effective grain filling period or kernel

5 growth rates as suggested elsewhere (May and Sanford 1992; Calderini et al 2001).

(Figure 7 near here)

Yield penalty due to early sowing

Reduced grain yields from sowing before the optimum time were largely associated with the early maturing cultivars. For example, at locations where the general response

10 was quadratic the penalties were:- Calingiri (longer season) $<$ Carnamah, EGA Eagle Rock, GBA Ruby and Spear (medium-long season) < EGA Bonnie Rock and Wyalkatchem (medium-short season) < Tammarin Rock and Westonia (short season). The general connection between cultivar maturity and optimum sowing time has been shown in other work for several environments (Coventry et al. 1993, Penrose 1993, Anderson et

15 al 1996) but the relative yield penalties due to early sowing as shown by this study have been less clear. Hence the simplest, reliable approach to reduce the yield penalty for early sowing would be to use only long duration cultivars in the event of an early break. However, there were exceptions at two warmer, short season, northern sites in 2005 (Eradu, Mullewa ) where the long and mid season cultivars (Calingiri and Carnamah)

20 were penalised more than the shorter season cultivars (Tammarin Rock and Wyalkatchem) in contrast to southern sites (Jerramungup), thus creating a $\mathrm{G} \times \mathrm{L}$ interaction (Figure 8). This result was associated with exceptionally good spring rains in 
the North that allowed longer season cultivars to yield relatively better at the later sowing time as compared to short season cultivars.

(Figure 8 near here)

The demonstration of yield penalties for early sowing in the quadratic type of responses at nine sites in this study implies that sowing as soon as possible after the break of the season advocated in earlier work (Delane and Hamblin, 1989; Anderson and Smith, 1990) may not always be advisable. Matching cultivars to sowing time is probably a better strategy for maximising grain yield.

The correlation analysis (based on relative values) of the whole dataset failed to show strong relationships and the data were divided into the following phases of yield response (Table 6):

a) The early increasing response period

b) The initial decline period after the maximum yield (sowings up to mid-June)

c) The later decline period (sowing after mid-June)

(Table 6 near here)

In the initial decline phase (Table 6b)after the highest grain yield, grain numbers were strongly correlated with grain yield and grain number in turn was best related to ear size.

20 In the later decline period (Table 6c) however, there were no significant correlations between any of the relative yield components and the relative grain yield. In the early 
yield increasing phase (Table 6a), grain numbers were also well correlated to grain yield but grain numbers $/ \mathrm{m}^{2}$ were equally related to both ear number and ear size. Spikelet number, the first determinant of grain number $/ \mathrm{m}^{2}$, is set early in the season before the onset of seasonal stress. Grains/spikelet, the second determinant of grains $/ \mathrm{m}^{2}$ in contrast

5 are set later in the season at around anthesis, when temperature and moisture conditions are more likely to be stressful. Thus earlier sown crops are likely to have greater flexibility to adjust grains $/ \mathrm{m}^{2}$ in response to seasonal influences. There was also a statistically significant correlation between relative grain yield and relative grain weight for early sown, but not later sown crops $(\mathrm{r}=-0.52,-0.36$ and -0.02 for early May, late

10 May, early June sowings, respectively) reflecting the possibility of more favourable conditions during grain filling of the earlier sowings.

These differences in the relative contribution of the various yield components to grain yield are complicated by differences between cultivars. For example, in the linear regression of relative grain yield on relative grain numbers (Figures 9a) the residual

15 variance was proportionately much greater for Carnamah (63.7 out of a total of 68.5) than that for EGA Eagle Rock (48.3 out of a total of 100.8) There was a significant negative linear trend for changes in grain weight in response to changes in grain numbers per spike (Figures 9b) and per $\mathrm{m}^{2}$ (Figures 9c) for Carnamah ( $\mathrm{p}<0.0001$ and $\mathrm{p}<0.10$, respectively). In contrast no such relationship was found for EGA Eagle Rock suggesting that 20 contrasting tendencies exist between cultivars for compensation between yield components. The tendency of EGA Eagle Rock to maintain constant grain size was observed to be associated with a characteristic of the ears to remain somewhat greener well after the leaves had senesced (Sharma DL, unpublished). 
(Figures 9 near here)

Amongst the tested cultivars, Wyalkatchem, Calingiri and Carnamah were the ones with most deviance $(>90 \%)$ from the linear regression of relative grain yield and relative grain numbers $/ \mathrm{m}^{2}$. This suggests that grain size can compensate for low grain numbers in

5 these three cultivars more efficiently than other cultivars. The ability of cultivars to adjust kernel weight rather than grain numbers can be related to adaptation (Borras et al 2003). This relationship between grain yield and grain numbers can, therefore, possibly be used to devise an index for adaptation to variable environments so that source limited grain yield potential could consistently be achieved despite the variation in sink size caused by

10 environmental factors. A high adaptation index would mean greater adaptation to seasonal stresses including late sowing, and would, therefore, be useful for adaptation in rainfed areas with high seasonal variability. This should provide stability against both controllable and uncontrollable causes of yield variation and thus promote regional varietal predominance. In fact Wyalkatchem, Calingiri and Carnamah were the top three

15 cultivars grown in Western Australia in 2005 with $26 \%, 20 \%$ and $12 \%$, respectively of the area sown, adding some weight to the idea that compensation between yield components can be important in adaptation to a range of environmental conditions.

\section{Analysis of variance for grain yield}

20 In this data set $70 \%$ of the variance for grain yield was accounted for by the location, the year and the interaction between these factors (Table 7). Sowing time (factor levels defined by 10 day intervals) accounted for $10 \%$ of the variance, but cultivar and the interaction between sowing time and cultivar accounted for less than $1 \%$ each. The high 
percentage of year $\mathrm{x}$ location variance $(24 \%)$ is related to the wide geographical spread of our experimental locations where seasonal influences can be quite different within the year.

(Table 7 near here)

5 The fact that sowing time accounted for a much greater share of the yield variance compared to cultivar $(10 \% \mathrm{cf}<1 \%$ in Table 7$)$ and that none of the environmental factors associated with Tmax (Table 4) are directly amenable to management, suggests that recognising the optimum sowing period each year is more important for maximizing grain yield in the Western Australian cropping zone. This does not imply that selecting

10 the appropriate cultivar to sow on a given date in particular environments and seasons is not important. Of course, if the yield variance is examined at a given site or farm, the relative importance of time of sowing and cultivar will increase.

The small amount of variance accounted for by cultivars is not unexpected since all of the cultivars used were relatively well adapted to local conditions. The relative

15 importance of management in G x E studies is supported by Cooper et al (2001) who argued that a large component of the previously documented $\mathrm{G} \times \mathrm{E}$ interactions for grain yield of wheat in the northern Australian cropping areas might be in part a result of interactions between genotypes and management. It has also been shown that grain yield responses to fungicide sprays for wheat cultivars with varying levels of disease resistance

20 can be important (Ransom et al. 2007). Likewise, Berger et al (2004) have reported a highly significant $\mathrm{G} \times \mathrm{E}$ interaction in an international chickpea germplasm collection, but no significant $\mathrm{G} \times \mathrm{E}$ interaction between genotypes originating from geographically homogenous clusters of locations. However, in our study the cultivars were relatively 
well adapted to the local environment and it is pertinent to observe that their pathways to high yield were quite variable as evidenced by variation in yield components,. The scope for using this variability to breed higher-yielding and more adapted cultivars deserves further study.

\section{Conclusion}

This study has distinguished four types of yield response to sowing time that were associated with time of the opening rains, distribution and amount of seasonal rainfall, all factors associated with the level of grain yield achieved. We conclude that i) the differences between cultivars for Tmax are evident only in the seasons that break before

10 mid-May and the best strategy is to sow the long season cultivars as soon as possible; ii) early sowing and choice of cultivar is important for grain yield in the high yielding seasons and less so in the average and lower yielding seasons; iii) the duration of the optimum sowing window at a given location is inversely proportional to the yield potential implying that it is critical to sow at or close to the optimum time when the yield

15 potential is high, most common when the season breaks early; iv) the simplest strategy to reduce the penalty for sowing before or after the optimum time could be to use only long duration cultivars provided that there is no loss of grain quality; and, v) most (70\%) of the grain yield variation was accounted for by uncontrollable factors of location and season, a substantial proportion $(10 \%)$ arose due to sowing time as well, while cultivar factors

20 caused the least variance in $\operatorname{Tmax}(1 \%)$.

In practice, at the time of the opening rains each year the presence or absence of stored moisture is known or can be estimated, the date relative to the optimum sowing time is known, the probabilities of various seasonal rainfall amounts can be estimated from 
seasonal forecast and the relative maturities of the cultivars on hand is known. This information can be used, together with the results reported in this paper to assist in making beneficial choices in respect of sowing times and choice of cultivar to maximise yield, and reduce risk. For later sowings choice of cultivar may however, be based on

5 factors other than grain yield (grain quality and possibly disease resistances for example) since differences in yield levels are relatively minor.

\section{Acknowledgements}

We are grateful to the staff of Avondale, Esperance, Katanning, Mullewa and Merredin Research Support Units for sowing and harvesting field experiments and to Bruce Haig,

10 Anne Smith, Melaine Kupsch and Judith Devenish for technical support in the data collection. Financial support from the Grains Research Development Corporation is gratefully acknowledged.

\section{References}

Anderson WK (1992) Increasing grain yield and water use of wheat in a rainfed Mediterranean type environment. Australian Journal of Agricultural Research 43, $1-17$.

Anderson WK, Smith WR (1990a) Yield advantage of two semi-dwarf compared to two tall wheats depends on sowing time. Australian Journal of Agricultural Research 41, 811-726.

20 Anderson WK, Smith WR (1990b) Increasing wheat yields in a high rainfall area of Western Australia. Australian Journal of Experimental Agriculture 30, 607-614.

Anderson WK, A. Heinrich A, Abbotts R (1996) Long season wheats extend sowing opportunities in the central wheat belt of Western Australia. Australian Journal of 
Experimental Agriculture 36, 203 - 208.

Anderson WK, Hamza MA, Sharma DL, D’Antuono MF, Hoyle FC, Hill N, Shackley BJ, Amjad M, Zaicou-Kunesch C (2005) The role of management in yield improvement of the wheat crop - a review with special emphasis on Western Australia. Australian Journal of Agricultural Research 56, 1137-1149.

Anderson W, Young K, Seymour M, French R, Shackley B, Abbotts R, Hoyle F, Kerr N, Loss S (1994). Flowering responses of crops in Western Australia. Department of Agriculture Western Australia Division of Plant Industries Technical Report No. 65.

10 Angus JF, Mackenzie DH, Morton R, Schafer CA (1981) Phasic development in field crops II. Thermal and photoperiodic responses of spring wheat. Field Crops Research 4, 269-283.

Berger JD, Turner NC, Siddique KHM, Knights EJ, Brinsmead RB, Mock I, Edmondson C, Khan TN (2004) Genotype by environment studies across Australia reveal the importance of phenology for chickpea (Cicer arietinum L.) improvement. Australian Journal of Agricultural Research 55, 1071-1084.

Borras L, Slafer GA, Otegui ME (2003) Seed dry weight response to source-sink manipulations in wheat, maize and soybean: a quantitative reappraisal. Field Crops Research 86, 131-146.

20 Byerlee D (1994) Technology transfer systems for improved crop management: Lessons for the future. In: 'Agricultural Technology: Policy issues for the international community' (Ed. JR Anderson), pp 208-230. Commonwealth Agricultural Bureaux International: Cambridge. 
Calderini DF, Savin R, Abeledo LG, Reynolds MP, Slafer GA (2001) The importance of the period immediately preceding anthesis for grain weight determination in wheat. Euphytica 119, 199-204.

Cooper M, Woodruff DR, Phillips IG, Basford KE, Gilmour AR (2001) Genotype-bymanagement interactions for grain yield and grain protein concentration of wheat. Field Crops Research 69, 47-67.

Coventry DR, Reeves TG, Brooke HD, Cann DK (1993) Influence of genotype, sowing date, and seeding rate on wheat development and yield. Australian Journal of Experimental Agriculture 33, 751 - 757.

10 Crofts HJ, Gardner WK, Velthuis RG (1984) A phenological evaluation of wheat for South-western Victoria. Australian Journal of Agricultural Research 35, 521-528.

Davidson JL, Christian KR, Jones DB, Bremner PM (1985) Responses of wheat to vernalisation and photoperiod. Australian Journal of Agricultural Research 36, 347-359.

15 Delane RJ, Hamblin J (1989) Early Sowing of Cereal Crops in Low Rainfall Areas. WA Journal of Agriculture 30, 41-43.

Del Cima R, D’Antuono MF, Anderson WK (2004) The effects of soil type and seasonal rainfall on the optimum sowing rate for wheat in Western Australia. Australian Journal of Experimental Agriculture 42, 585-594.

20 Donald CM, Puckridge DW (1975) The ecology of the wheat crop. In: 'Australian Field Crops, Volume 1' (Eds. A Lazenby, E. M. Matheson), pp. 288-303. Angus and Robertson, Sydney.

Doyle AD, Marcellos H (1974) Time of sowing and wheat yield in northern New South 
Wales. Australian Journal of Experimental Agriculture and Animal Husbandry 14, $93-102$.

Farrer W (1898) The making and improvement of wheats for Australian conditions. Agricultural Gazette of New South Wales 9, 131-167.

5 Fischer RA, Kohn GD (1966) The relationship of grain yield to vegetative growth and post-flowering leaf area in the wheat crop under condition of limited soil moisture. Australian Journal of Agricultural Research 17, 281-295.

French RJ, Schultz JE (1984) Water use efficiency of wheat in a Mediterranean-type environment. II. Some limitations to efficiency. Australian Journal of Agricultural Research 35, 765-775.

French RJ, Schultz JE, Rudd CL (1979) Effect of time of sowing on wheat phenology in South Australia. Australian Journal of Experimental Agriculture and Animal Husbandry 19, 89-96.

Gabriel, K.R. (1971). The biplot graphic display of matrices with application to principal component analysis. Biometrika 58, 453.

GenStat for Windows ${ }^{\circledR}$ (2006) Edition 9. VSN International, United Kingdom. http:// www.vsni.co.uk

Gott MB (1961) Flowering of Australian wheats and its relation to frost injury. Australian Journal of Agricultural Research 12, 547-565.

20 Kerr NJ, Siddique KHM, Delane RJ (1992) Early sowing with wheat cultivars of suitable maturity increases grain yield of spring wheat in a short season environment. Australian Journal of Experimental Agriculture 32, 717-723.

Kohn GD, Storrier RR (1970) Time of sowing and wheat production in southern New 
South Wales. Australian Journal of Experimental Agriculture and Animal Husbandry 10, $604-609$.

Mason MG, Glencross RN, Nicholas DA, Wilkinson HF (1978) Effect of time and rate of sowing cereals on the response to nitrogen fertilizers and the influence of time of nitrogen application. Technical Bulletin No. 40. Department of Agriculture of Western Australia, South Perth, pp15.

May L, Van Sanford DA (1992) Selection for early heading and correlated response in maturity of soft red winter wheat. Crop Sci. 32, 47-51.

Moore G, Hall D, Russell J (1998). Soil water. In 'Soilguide. A handbook for understanding and managing agricultural soils.' (Ed. G Moore) Agriculture Western Australia Bulletin No. 4343, pp 80-93. Agriculture Western Australia.

O'Leary GJ, Connor DJ, White DH (1985) Effect of sowing time on growth, yield and water use of rain-fed wheat in the Wimmera, Vic. Australian Journal of Agricultural Research 36, 187 - 196.

15 Penrose LDJ (1993). Yield of early dryland sowing of wheat with winter and spring habit in southern and central New South Wales. Australian Journal of Experimental Agriculture 33, 601-608.

Pugsley AT (1965). Inheritance of a correlated daylength response in spring wheat. Nature 207, 108.

20 R Development Core Team (2006) R: A Language and Environment for Statistical Computing, R Development Core Team, R Foundation for Statistical Computing, Vienna, Austria, version 2.5.1, 2007. URL http://www.R-project.org

Ransom JK, Endres GJ, Schatz BG 2007. Sustainable improvement of wheat yield 
potential: the role of crop management. Journal of Agricultural Science 145, 55-61.

ASREML library for $\mathrm{R}^{\circledR}$ Statistical System (2006) VSN International, United Kingdom. http:// www.vsni.co.uk

Schmidt CP, Belford RK (1993) A comparison of different tillage-seeding systems: the interaction of tillage and time of sowing on sandplain soils in Western Australia. Australian Journal of Experimental Agriculture 33, 895-900.

Schoknecht N (2002) Soil groups of Western Australia: a simple guide to the main soils of Western Australia. Department of Agriculture, Government of Resource Management Technical Report No. 246, Western Australia.

10 Shackley BJ (2000) Crop management. In: 'The Wheat Book - principles and practice' (Eds. WK Anderson, JR Garlinge) pp. 131-163 Agriculture Western Australia Bulletin 4443.

Shackley BJ, Anderson WK (1995). Responses of wheat cultivars to time of sowing in the southern wheatbelt of Western Australia. Australian Journal of Experimental Agriculture 35, 579 - 587.

Single WV (1961) Studies on frost injury in wheat. 1. Laboratory freezing tests in relation to the behaviour of cultivars in the field. Australian Journal of Agricultural Research 12, 767- 782 .

Stephens DJ, Lyons TJ 1998. Variability and trends in sowing dates across the Australian wheatbelt. Australian Journal of Agricultural Research 49, 1111-1118.

Syme JR (1968) Ear emergence of Australian, Mexican and European wheats in relation to time of sowing and their response to vernalization and day length. Australian Journal of Experimental Agriculture and Animal Husbandry 8, 578 - 581. 
Verbyla AP, Cullis BR, Kenward MG, Welham SJ (1999) The analysis of designed experiments and longitudinal data by using smoothing splines. Applied Statistics 48, 269-311.

Woodruff DR, Tonks J (1983) Relationship between time of anthesis and grain yield of wheat genotypes with differing developmental patterns. Australian Journal of Agricultural Research 34, 1-11. 
Table 1 Summary of published research into sowing times for wheat in Australia 1970 to 2000.

\begin{tabular}{|c|c|c|c|c|}
\hline Reference & $\begin{array}{l}\text { Percent } \\
\text { (approx.) of } \\
\text { rain in growing } \\
\text { season, location } \\
\text { and approx. } \\
\text { latitude }\end{array}$ & $\begin{array}{l}\text { Experimental } \\
\text { treatments }\end{array}$ & $\begin{array}{l}\text { Optimum } \\
\text { sowing period }\end{array}$ & $\begin{array}{l}\text { Yield decline } \\
\text { after optimum } \\
\text { period } \\
\text { (kg/ha.day) }\end{array}$ \\
\hline $\begin{array}{l}\text { Woodruff and } \\
\text { Tonks (1983) }\end{array}$ & $\begin{array}{l}<40, \\
\text { Central } \\
\text { Queensland, } \\
28^{0} \mathrm{~S}\end{array}$ & $\begin{array}{l}\text { Sowings from } \\
\text { early May to } \\
\text { late September, } \\
\text { range of } \\
\text { cultivars, } 4 \\
\text { years }\end{array}$ & $\begin{array}{l}\text { Mid May to late } \\
\text { June }\end{array}$ & 36 \\
\hline $\begin{array}{l}\text { Doyle and } \\
\text { Marcellos } \\
\text { (1974) }\end{array}$ & $\begin{array}{l}<40, \\
\text { Tamworth } \\
\text { northern NSW, } \\
32^{0} \mathrm{~S}\end{array}$ & $\begin{array}{l}\text { Sowings from } \\
\text { mid May to } \\
\text { early October, } \\
\text { range of } \\
\text { cultivars, } 5 \\
\text { years }\end{array}$ & Late June & 39 \\
\hline Penrose (1993) & $\begin{array}{l}40-50, \\
\text { Central and } \\
\text { southern NSW, } \\
33^{0} \mathrm{~S}\end{array}$ & $\begin{array}{l}\text { Sowings from } \\
\text { mid April to } \\
\text { late May, } \\
\text { spring and } \\
\text { winter } \\
\text { cultivars, } 10 \\
\text { years }\end{array}$ & $\begin{array}{l}\text { Late April for } \\
\text { winter types, } \\
\text { early May for } \\
\text { spring types }\end{array}$ & [Linear decline] \\
\hline $\begin{array}{l}\text { Kohn and } \\
\text { Storrier (1970) }\end{array}$ & $\begin{array}{l}50, \\
\text { Wagga Wagga }\end{array}$ & $\begin{array}{l}\text { Sowings from } \\
\text { late April to }\end{array}$ & Early May & $15-20$ \\
\hline
\end{tabular}




\begin{tabular}{|c|c|c|c|c|}
\hline & $\mathrm{NSW}, 35^{\circ} \mathrm{S}$ & $\begin{array}{l}\text { early August, } \\
\text { CV Heron, } 5 \\
\text { years }\end{array}$ & & \\
\hline $\begin{array}{l}\text { Coventry et al } \\
\text { (1993) }\end{array}$ & $\begin{array}{l}50-60, \\
\text { Rutherglen } \\
\text { Victoria, } 37^{0} \mathrm{~S}\end{array}$ & $\begin{array}{l}\text { Sowings from } \\
\text { mid April to } \\
\text { early August, } \\
\text { short, mid and } \\
\text { long season } \\
\text { cultivars, } 3 \\
\text { years }\end{array}$ & $\begin{array}{l}\text { Long season } \\
\text { CVs - mid } \\
\text { April to mid } \\
\text { May, Mid } \\
\text { season cultivars } \\
\text { - mid April to } \\
\text { mid June, short } \\
\text { season cultivars } \\
\text { - mid May to } \\
\text { mid June }\end{array}$ & $7-36$ \\
\hline $\begin{array}{l}\text { O'Leary et al } \\
(1985)\end{array}$ & $\begin{array}{l}60, \\
\text { Dooen Victoria, } \\
38^{0} \mathrm{~S}\end{array}$ & $\begin{array}{l}\text { Sowings from } \\
\text { mid April to } \\
\text { mid August, } \\
\text { CV Olympic, } 2 \\
\text { years }\end{array}$ & June & $13-20$ \\
\hline $\begin{array}{l}\text { French and } \\
\text { Schultz (1984) }\end{array}$ & $\begin{array}{l}60, \\
\text { South } \\
\text { Australia, } 35^{0} \mathrm{~S}\end{array}$ & $\begin{array}{l}\text { Farmer } \\
\text { experience }\end{array}$ & $\begin{array}{l}\text { Mid may to mid } \\
\text { June }\end{array}$ & $13-36$ \\
\hline $\begin{array}{l}\text { Kerr et al } \\
\text { (1992) }\end{array}$ & $\begin{array}{l}70, \\
\text { Geraldton } \\
\text { Western, } \\
\text { Australia, } 28^{0} \mathrm{~S}\end{array}$ & $\begin{array}{l}\text { Sowings from } \\
\text { early May to } \\
\text { late June, range } \\
\text { of cultivars, } 3 \\
\text { years }\end{array}$ & $\begin{array}{l}\text { Mid may to } \\
\text { early June }\end{array}$ & 36 \\
\hline $\begin{array}{l}\text { Anderson and } \\
\text { Smith (1990a) }\end{array}$ & $\begin{array}{l}70, \\
\text { Central region } \\
\text { Western } \\
\text { Australia, } 32^{0} \mathrm{~S}\end{array}$ & $\begin{array}{l}\text { Sowings from } \\
\text { mid May to } \\
\text { early July, } 4 \\
\text { cultivars, } 3\end{array}$ & May & $13-42$ \\
\hline
\end{tabular}




\begin{tabular}{|c|c|c|c|c|}
\hline & & years & & \\
\hline $\begin{array}{l}\text { Anderson et al } \\
\text { (1996) }\end{array}$ & $\begin{array}{l}70, \\
\text { Central region } \\
\text { Western } \\
\text { Australia, } 32^{0} \mathrm{~S}\end{array}$ & $\begin{array}{l}\text { Sowings from } \\
\text { early April to } \\
\text { mid June, short, } \\
\text { mid and long } \\
\text { season } \\
\text { cultivars, } 3 \\
\text { years }\end{array}$ & $\begin{array}{l}\text { Late April to } \\
\text { late May }\end{array}$ & $16-27$ \\
\hline $\begin{array}{l}\text { Shackley and } \\
\text { Anderson } \\
\text { (1995) }\end{array}$ & $\begin{array}{l}70, \\
\text { Great Southern } \\
\text { region Western } \\
\text { Australia, } 33^{0} \mathrm{~S}\end{array}$ & $\begin{array}{l}\text { Sowings from } \\
\text { late April to } \\
\text { early July, } \\
\text { range of } \\
\text { cultivars, } 3 \\
\text { years }\end{array}$ & Early May & 20 \\
\hline $\begin{array}{l}\text { Shackley } \\
(2000)\end{array}$ & $\begin{array}{l}70, \\
\text { North-east, } \\
\text { Central, South } \\
\text { and South } \\
\text { Coast, Western } \\
\text { Australia, 28- } \\
34^{0} \mathrm{~S}\end{array}$ & $\begin{array}{l}\text { Summary of } \\
\text { many } \\
\text { experiments - } \\
\text { cultivars } \mathrm{x} \\
\text { sowing times }\end{array}$ & $\begin{array}{l}\text { North-east - } \\
\text { mid May to } \\
\text { early June } \\
\text { Central - late } \\
\text { April to mid } \\
\text { May } \\
\text { South - early } \\
\text { May to early } \\
\text { June } \\
\text { South Coast - } \\
\text { Early May to } \\
\text { early June }\end{array}$ & $\begin{array}{l}\text { NE }-35 \\
\text { Central }-25 \\
\text { South }-25 \\
\text { S. Coast - } 17\end{array}$ \\
\hline
\end{tabular}


Table 2 Trial site details, 2003 - 2005.

\begin{tabular}{|c|c|c|c|c|c|c|c|c|}
\hline \multirow{2}{*}{$\begin{array}{l}\text { Location and } \\
\text { year }\end{array}$} & \multirow{2}{*}{$\begin{array}{l}\text { Latitude } \\
\left({ }^{0} \mathrm{~S}\right)\end{array}$} & \multirow{2}{*}{$\begin{array}{l}\text { Longitude } \\
\left({ }^{0} \mathrm{E}\right)\end{array}$} & \multirow{2}{*}{$\begin{array}{l}\text { Rainfall } \\
\text { (April to } \\
\text { October) } \\
\text { mm }\end{array}$} & \multirow[t]{2}{*}{ Soil type } & \multirow[t]{2}{*}{ Previous crop } & \multicolumn{3}{|c|}{ Sowing dates } \\
\hline & & & & & & 1 & 2 & 3 \\
\hline \multicolumn{9}{|l|}{2003} \\
\hline Mullewa & 28.58 & 115.45 & 167 & Sandy loam & Lupin & 10-May & 24-May & 10-Jun \\
\hline Mingenew & 29.28 & 115.38 & 344 & Yellow sandplain & Lupin & 14-May & 27-May & 11-Jun \\
\hline Mukinbudin & 31.03 & 118.17 & 283 & Clay loam & Lentil & 23-May & 06-Jun & 20-Jun \\
\hline Merredin $^{\mathrm{a}}$ & 31.48 & 118.22 & 280 & Sandy clay & Medic pasture & 03-Jun & 17-Jun & 01-Jul \\
\hline Quairading $^{\mathrm{a}}$ & 32.02 & 117.52 & 259 & Sandy duplex & Lupins & 30-May & 12-Jun & 26-Jun \\
\hline Salmon Gums & 33.08 & 121.67 & 468 & Mallee & Pasture & 26-May & 10-Jun & 24-Jun \\
\hline Gibson & 33.62 & 121.77 & 482 & Sandplain & Lupin & 28-May & 13-Jun & 25-Jun \\
\hline Nyabing & 33.58 & 118.37 & 347 & Clay loam & Fallow & 22-May & 03-Jun & 25-Jun \\
\hline Katanning & 33.68 & 117.58 & 362 & Sandy duplex & Lupin & 22-May & 06-Jun & 23-Jun \\
\hline \multicolumn{9}{|l|}{2004} \\
\hline Mullewa & 28.58 & 115.45 & 184 & Sandy loam & Lupin & 26-May & 10-Jun & \\
\hline Eradu & 28.68 & 114.97 & 315 & Yellow sandplain & Pasture & 27-May & 11-Jun & 22-Jun \\
\hline Mukinbudin & 31.03 & 118.17 & 208 & Clay loam & Chickpea & 28-May & 10-Jun & 25-Jun \\
\hline Quairading & 32.02 & 117.52 & 245 & Sandy duplex & Lupin & 04-Jun & 14-Jun & 28-Jun \\
\hline Salmon Gums & 33.08 & 121.67 & 388 & Mallee & Pasture & 03-Jun & 17-Jun & 01-Jul \\
\hline Scaddan & 33.47 & 121.53 & 287 & Duplex & Field peas & 01-Jun & 16-Jun & 01-Jul \\
\hline Gibson $^{\mathrm{a}}$ & 33.62 & 121.77 & 323 & Sandplain & Lupin & 29-May & 15-Jun & 30-Jun \\
\hline Jerramungup & 33.88 & 118.82 & 337 & Shallow clay loam & Canola & 03-Jun & 30-Jun & 14-Jul \\
\hline \multicolumn{9}{|l|}{2005} \\
\hline Mullewa & 28.58 & 115.45 & 211 & Sandy loam & Lupin & 03-May & 23-May & 08-Jun \\
\hline Eradu & 28.68 & 114.97 & 417 & Yellow sandplain & Lupin & 02-May & 23-May & 08-Jun \\
\hline Mukinbudin & 31.03 & 118.17 & 195 & Clay loam & Peas & 10-May & 25-May & 14-Jun \\
\hline Merredin ${ }^{\mathrm{b}}$ & 31.48 & 118.22 & 266 & Clay loam & Pasture & 06-May & 24-May & \\
\hline East Beverely & 32.11 & 116.93 & 407 & Grey sandy duplex & Lupins & 04-May & 31-May & \\
\hline
\end{tabular}




\begin{tabular}{lllllllll} 
Avondale & 32.12 & 116.87 & 407 & Clayey sand & Lupin & 06-May & 23-May & 15-Jun \\
Salmon Gums & 33.08 & 121.67 & 421 & Mallee & Pasture & 10-May & 26-May & 14-Jun \\
Jerramungup & 33.46 & 118.82 & 414 & Shallow clay loam & Canola & 06-May & 24-May & 14-Jun \\
Scaddan & 33.47 & 121.53 & 350 & Duplex & Field peas & 11-May & 30-May & 29-Jun \\
Gibson & 33.62 & 121.77 & 464 & Sandplain & Lupin & 05-May & 26-May & 16-Jun \\
\hline
\end{tabular}

${ }^{a}$ First time sown later than 14 days from the seasonal break (20ml over three days)

${ }^{\mathrm{b}}$ First time of sowing affected by frost 
Table 3 Tmax $\uparrow$ for nine cultivars at 27 experiments in WA.

\begin{tabular}{|c|c|c|c|c|c|c|c|c|c|c|c|}
\hline $\begin{array}{l}\text { Location and } \\
\text { year }\end{array}$ & $\begin{array}{l}\text { Day of } \\
\text { first } \\
\text { sowing }\end{array}$ & Calingiri & Carnamah & $\begin{array}{c}\text { EGA } \\
\text { Bonnie } \\
\text { Rock }\end{array}$ & $\begin{array}{l}\text { EGA } \\
\text { Eagle } \\
\text { Rock }\end{array}$ & $\begin{array}{l}\text { GBA } \\
\text { Ruby }\end{array}$ & Spear & $\begin{array}{l}\text { Tammarin } \\
\text { Rock }\end{array}$ & Westonia & Wyalkatchem & $\begin{array}{l}\text { Standard } \\
\text { deviation }\end{array}$ \\
\hline \multicolumn{12}{|l|}{2003} \\
\hline Merredin ${ }^{\mathrm{a}}$ & 154 & \multicolumn{9}{|c|}{ Tmax for all cultivars $=154$} & 0.0 \\
\hline Quairading $^{\mathrm{a}}$ & 150 & \multicolumn{9}{|c|}{ Tmax for all cultivars $=150$} & 0.0 \\
\hline Mingenew & 134 & 134 & 134 & 141 & 134 & 134 & 134 & 134 & 134 & 134 & 2.3 \\
\hline $\begin{array}{l}\text { Mullewa } \\
\text { Salmon }\end{array}$ & 130 & 143 & 143 & 146 & 141 & 143 & 144 & 143 & 144 & 152 & 3.2 \\
\hline Gums & 146 & \multicolumn{9}{|c|}{ Tmax for all cultivars $=146$} & 0.0 \\
\hline Gibson & 148 & 164 & 165 & 161 & 165 & 168 & 156 & 162 & 161 & 164 & 3.4 \\
\hline Nyabing & 142 & 142 & 142 & 142 & 142 & 142 & 142 & $*$ & 142 & 154 & 4.2 \\
\hline Katanning & 143 & 143 & 143 & 143 & 143 & 143 & 143 & 159 & 143 & 143 & 5.3 \\
\hline Mukinbudin & 143 & \multicolumn{9}{|c|}{ Tmax for all cultivars $=143$} & 0.0 \\
\hline \multicolumn{12}{|l|}{2004} \\
\hline Quairading & 156 & 165 & 180 & 180 & 167 & 170 & 166 & 170 & 164 & 158 & 7.2 \\
\hline Eradu & 148 & \multicolumn{9}{|c|}{ Tmax for all cultivars $=148$} & 0.0 \\
\hline Mullewa & 147 & 147 & 147 & 162 & 147 & 162 & 162 & 162 & 162 & 162 & 7.5 \\
\hline $\begin{array}{l}\text { Gibson } \\
\text { Salmon }\end{array}$ & 150 & \multicolumn{9}{|c|}{ Tmax for all cultivars $=150$} & 0.0 \\
\hline Gums & 155 & \multicolumn{9}{|c|}{ Tmax for all cultivars $=155$} & 0.0 \\
\hline Scaddan & 153 & \multicolumn{9}{|c|}{ Tmax for all cultivars $=153$} & 0.0 \\
\hline Mukinbudin & 149 & 149 & 149 & $\mathrm{D}$ & 149 & 149 & 153 & 156 & 149 & 149 & 2.5 \\
\hline Jerramungup & 153 & \multicolumn{9}{|c|}{ Tmax for all cultivars $=153$} & 0.0 \\
\hline \multicolumn{12}{|l|}{2005} \\
\hline \multicolumn{12}{|l|}{ East } \\
\hline Beverley & 124 & 124 & 151 & 151 & 151 & 151 & 151 & 151 & 151 & 151 & 9.0 \\
\hline Avondale & 126 & 126 & 137 & 143 & 140 & 141 & 126 & 145 & 145 & 144 & 7.6 \\
\hline Eradu & 122 & 144 & 140 & 159 & 148 & 142 & 143 & 131 & 141 & 159 & 9.0 \\
\hline Mullewa & 123 & 143 & 142 & 123 & 141 & 142 & 144 & 123 & 137 & 137 & 8.2 \\
\hline Gibson & 125 & 145 & 153 & 147 & 156 & 155 & 160 & 159 & 148 & 147 & 5.6 \\
\hline
\end{tabular}




\begin{tabular}{|c|c|c|c|c|c|c|c|c|c|c|c|}
\hline \multicolumn{12}{|l|}{ Salmon } \\
\hline Gums & 130 & 135 & 139 & 145 & 141 & 143 & 141 & 147 & 142 & 141 & 3.4 \\
\hline Scaddan & 131 & 151 & 152 & 152 & 151 & 152 & 151 & 153 & 151 & 150 & 0.9 \\
\hline Merredin ${ }^{\mathrm{b}}$ & 126 & \multicolumn{9}{|c|}{ Tmax for all cultivars $=144$} & 0.0 \\
\hline Mukinbudin & 130 & 138 & 130 & 144 & 133 & 142 & 130 & 146 & 146 & 146 & 6.9 \\
\hline Jerramungup & 126 & 141 & 140 & 148 & 143 & 141 & 142 & 149 & 146 & 150 & 3.8 \\
\hline
\end{tabular}

${ }^{\mathrm{a}}$ First time sown later than 14 days from the seasonal break ( $20 \mathrm{ml}$ over three days); excluded from further analysis

${ }^{\mathrm{b}}$ First time of sowing affected by frost

${ }^{\dagger}$ Estimates of standard error of Tmax were about 5\% 


\section{Table 4 Major factors affecting variance of Tmax at experimental sites whe re first sowing was done before mid-May and response to sowing time was of} 'quadratic' type.

The early quadratic experiments were: Avondale 2005, Eradu 2005, Gibson 2005, Jerramungup 2005, Mukinbudin 2005, Scaddan 2005, Salmon gums 2005,

5 Mullewa 2003 and Mullewa 2005; TS1 is the date of first sowing in each experiment, GSRF1 is growing season rainfall for the first sowing time, Heat winter is heatsums in May, June and July, Heat spring is the heatsums in August, September and October, Paw is estimated available water capacity for the soil type at each site.

\begin{tabular}{lclll}
\hline Cultivar & $\begin{array}{c}\text { \% variance of } \\
\text { Tmax } \\
\text { accounted for }\end{array}$ & & Explanatory variables \\
\hline Calingiri & 66.7 & Heat_winter & Latitude & GSRF1 \\
EGA Eagle Rock & 91.0 & Heat_winter & Latitude & Heat_spring \\
Carnamah & 73.2 & Heat_winter & Latitude & TS1 \\
Wyalkatchem & 67.5 & Heat_winter & Heat_spring & Paw \\
GBA Ruby & 95.4 & Longitude & Heat_spring & GSRF1 \\
Spear & 70.1 & Longitude & Heat_winter & \\
Tammarin Rock & 75.8 & Latitude & Heat_spring & \\
Westonia & 78.6 & TS1 & GSRF1 & Latitude \\
EGA Bonnie Rock & 37.2 & GSRF1 & TS1 & \\
\hline
\end{tabular}


Table 5. Average grain yield components from the highest yielding sowing time in all the 23 experiments

\begin{tabular}{|c|c|c|c|c|c|c|c|}
\hline $\begin{array}{l}\text { Location on } \\
\text { the biplot }\end{array}$ & Cultivar & $\begin{array}{c}\text { Number } \\
\text { of } \\
\text { heads } / \mathrm{m}^{2}\end{array}$ & Grains $/ m^{2}$ & Grains/head & Greentillers $/ \mathrm{m}^{2}$ & $\begin{array}{c}1000 \\
\text { Kernel } \\
\text { weight } \\
(\mathrm{g})\end{array}$ & $\begin{array}{l}\text { Harvest } \\
\text { index }\end{array}$ \\
\hline 1 & Calingiri & 278 & 8559 & 32 & 501 & 38 & 0.42 \\
\hline 2 & EGA Eagle Rock & 319 & 9105 & 30 & 471 & 31 & 0.41 \\
\hline 3 & Carnamah & 312 & 8755 & 29 & 447 & 34 & 0.38 \\
\hline 4 & Spear & 304 & 8292 & 30 & 427 & 34 & 0.38 \\
\hline 5 & GBA Ruby & 276 & 9179 & 36 & 420 & 34 & 0.41 \\
\hline 6 & Wyalkatchem & 320 & 8379 & 28 & 530 & 38 & 0.41 \\
\hline 7 & Westonia & 289 & 8537 & 32 & 391 & 37 & 0.43 \\
\hline 8 & EGA Bonnie Rock & 349 & 9224 & 28 & 467 & 34 & 0.41 \\
\hline 9 & Tammarin Rock & 295 & 7967 & 28 & 432 & 37 & 0.41 \\
\hline
\end{tabular}


Table 6 Corre lation coefficient of relative (to highest yielding time of sowing) grain yield and relative yield components in experiements that were sown in a) early-May sown, b) late-May sown and c) early June sown

5

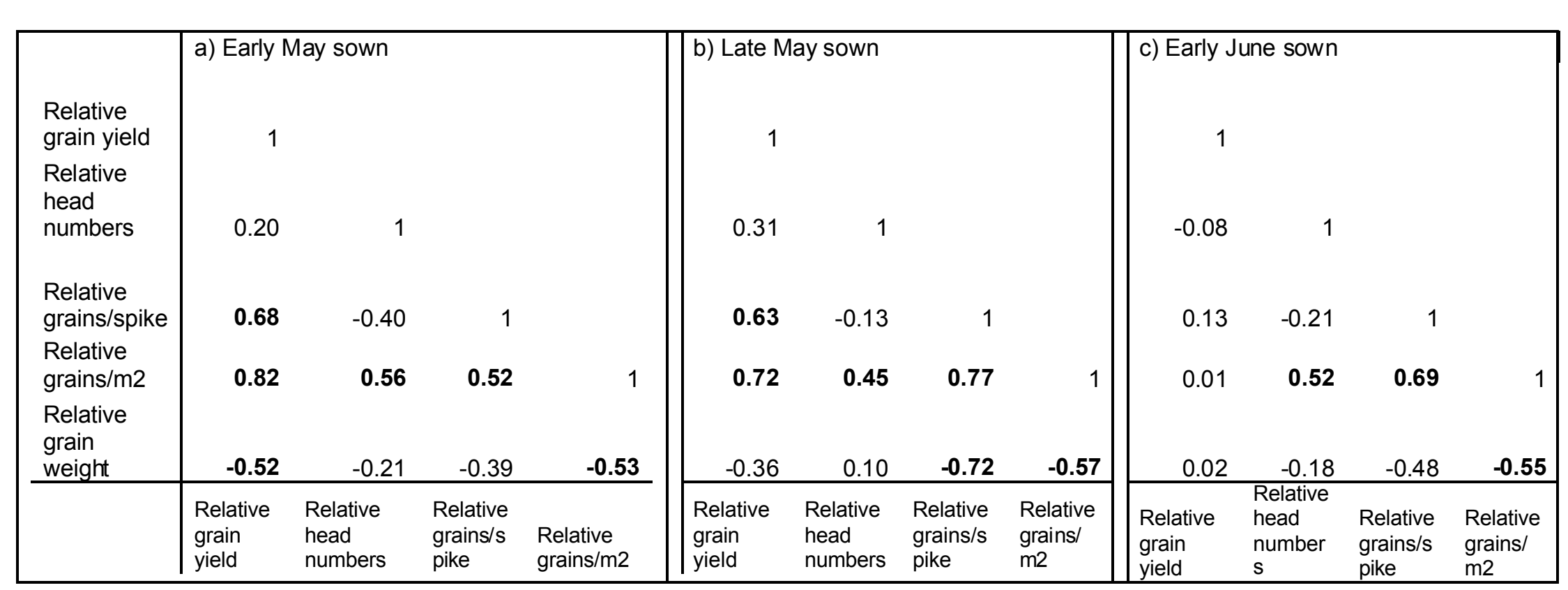

Figures in bold indicate statistically significant correlation 
Table 7. Percentage of yield variance accounted for by years, locations, time of sowing and genotypes in 23 experiments in Western Australia in 2003 to 2005.

Y, Year; L, Location; T, Time of sowing; G, Genotype

\begin{tabular}{lccc}
\hline $\begin{array}{l}\text { Source of } \\
\text { variation }\end{array}$ & $\begin{array}{c}\text { Variance } \\
\text { component }\end{array}$ & $\begin{array}{c}\text { Standard } \\
\text { error }\end{array}$ & $\begin{array}{c}\text { Percentage } \\
\text { of total } \\
\text { variance }\end{array}$ \\
\hline Y & 0.205 & 0.233 & 15 \\
L & 0.416 & 0.276 & 31 \\
Y.L & 0.322 & 0.159 & 24 \\
T & 0.134 & 0.093 & 10 \\
Y.T & 0.004 & 0.015 & $<1$ \\
L.T & 0.011 & 0.026 & 1 \\
Y.L.T & 0.046 & 0.029 & 3 \\
G & 0.004 & 0.005 & $<1$ \\
T.G & 0.005 & 0.002 & $<1$ \\
L.G & 0.013 & 0.004 & 1 \\
Y.G & 0.010 & 0.004 & 1 \\
Y.T.G & 0 & Bound & \\
L.T.G & 0.006 & 0.005 & $<1$ \\
Y.L.T.G & 0.015 & 0.005 & 1 \\
Residual & 0.081 & & 6 \\
TOTAL & 1.321 & & \\
\hline
\end{tabular}




\section{Figure 1}

Figure 2.

Figure 3.

Figure 4

$5 \quad$ Figure 5.

Figure 6

Figure 7

Figure 8

Figures 9a,b,c.

10 Captions to figures

Figure 1. Examples of four types of grain yield response to sowing time depicted using cultivar Spear in four experiments: Scadden 2005 (quadratic), Jerramungup 2004 (linear declining), Mullewa 2004 (linear rising) and Mukinbudin 2004 (flat).

15 Figure 2. Average grain yield of wheat cultivars at different dates of sowing at Avondale in 2005.

Figure 3. Grain yield response (modelled using smoothing splines) of two wheat cultivars to time of sowing at a) Eradu and b) Avondale in 2005.

20 Figure 4. Biplot depicting G x E interactions of Tmax for 9 cultivars in the 23 experiments. (The experiments sown later than 14 days from the break and the frost affected experiments were not included in this biplot). Environmental abbreviation comprise location name and year: Av Avondale, Eb East Beverley, Er Eradu, Gi Gibson, Je Jerramungup, Ka Katanning, Mi Mingenew, Mk Mukinbudin, Mw Mullewa, Qu Quairading, Sg Salmon Gums, Sc Scadden; 03 year 2003, 04 year2004, 05 year2005.

Figure 5. Ymax window (period between Tmax to the day corresponding to $10 \%$ decline in grain yield) for wheat cultivar Calingiri over different seasons at Mukinbudin

Figure 6. Grain yield decline of eight cultivars after the optimum sowing time at Mukinbudin in 2003, 302004 and 2005. The highest yielding sowing dates were $23^{\text {rd }}$ May, $28^{\text {th }}$ May and $25^{\text {th }}$ May with average yield levels of $3.03 \mathrm{t} / \mathrm{ha}, 0.77 \mathrm{t} / \mathrm{ha}$ and $2.07 \mathrm{t} / \mathrm{ha}$ for the three years, respectively. Size of squares highlights the extent of differences among cultivars against average yield levels.

Figure 7. Grain yield decline for three cultivars from sowing after the Tmax in seven experiments where Tmax was similar among these three cultivars within each experiment.

Figure 8. Grain yield loss for four cultivars from early sowing in the north (shaded bars; Eradu 2005) vs. south (unshaded bars; Jerra mungup 2005) in two trials similar for dates of first sowing (day 122, 126), plant available water $(110,120 \mathrm{~mm})$ and growing season rainfall $(417,414 \mathrm{~mm})$.

Figures 9. Change in relative yield components and grain yield of two cultivars contrasting for compensation during the periods when grain yield of all cultivars was in a declining phase. 


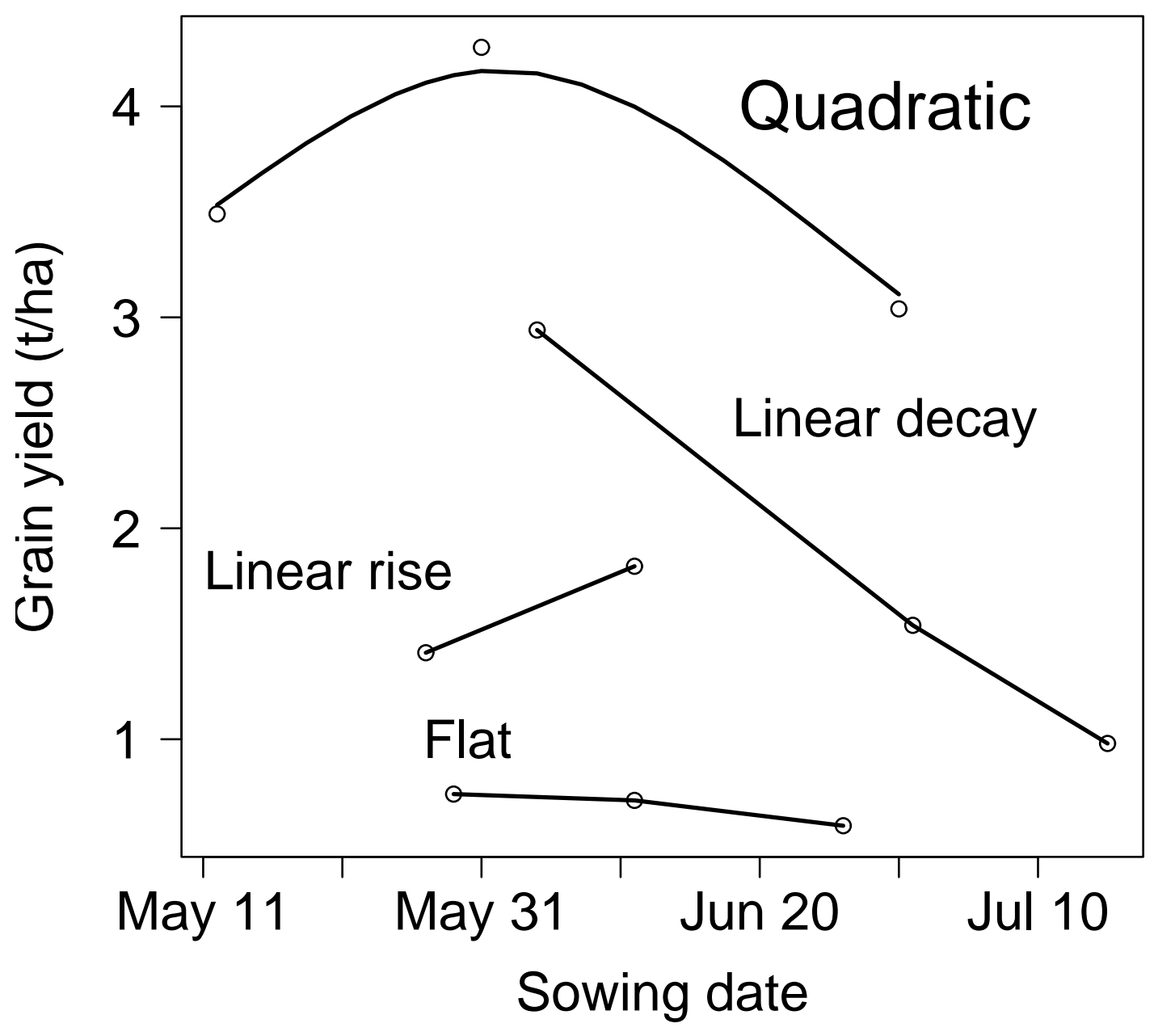




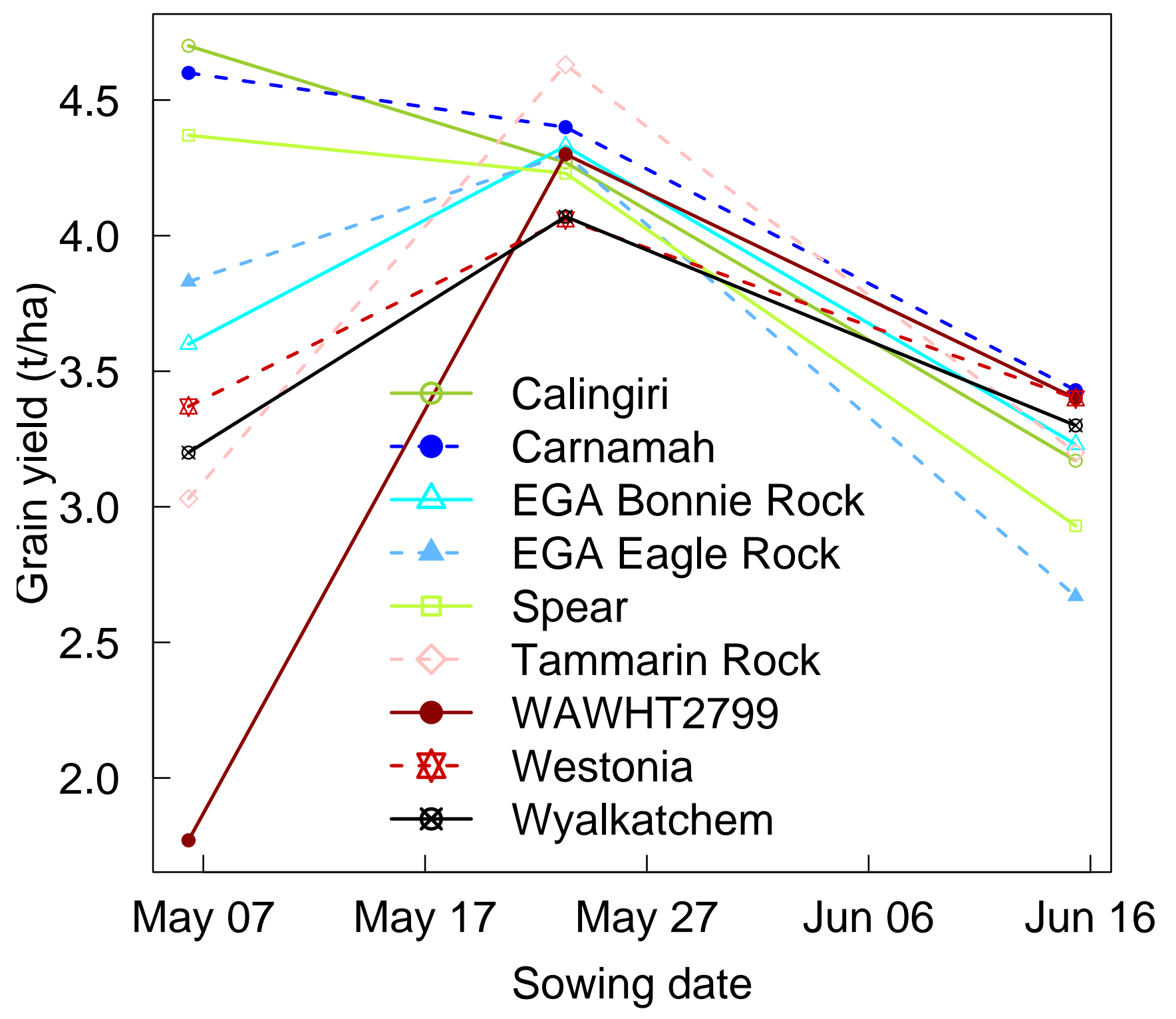



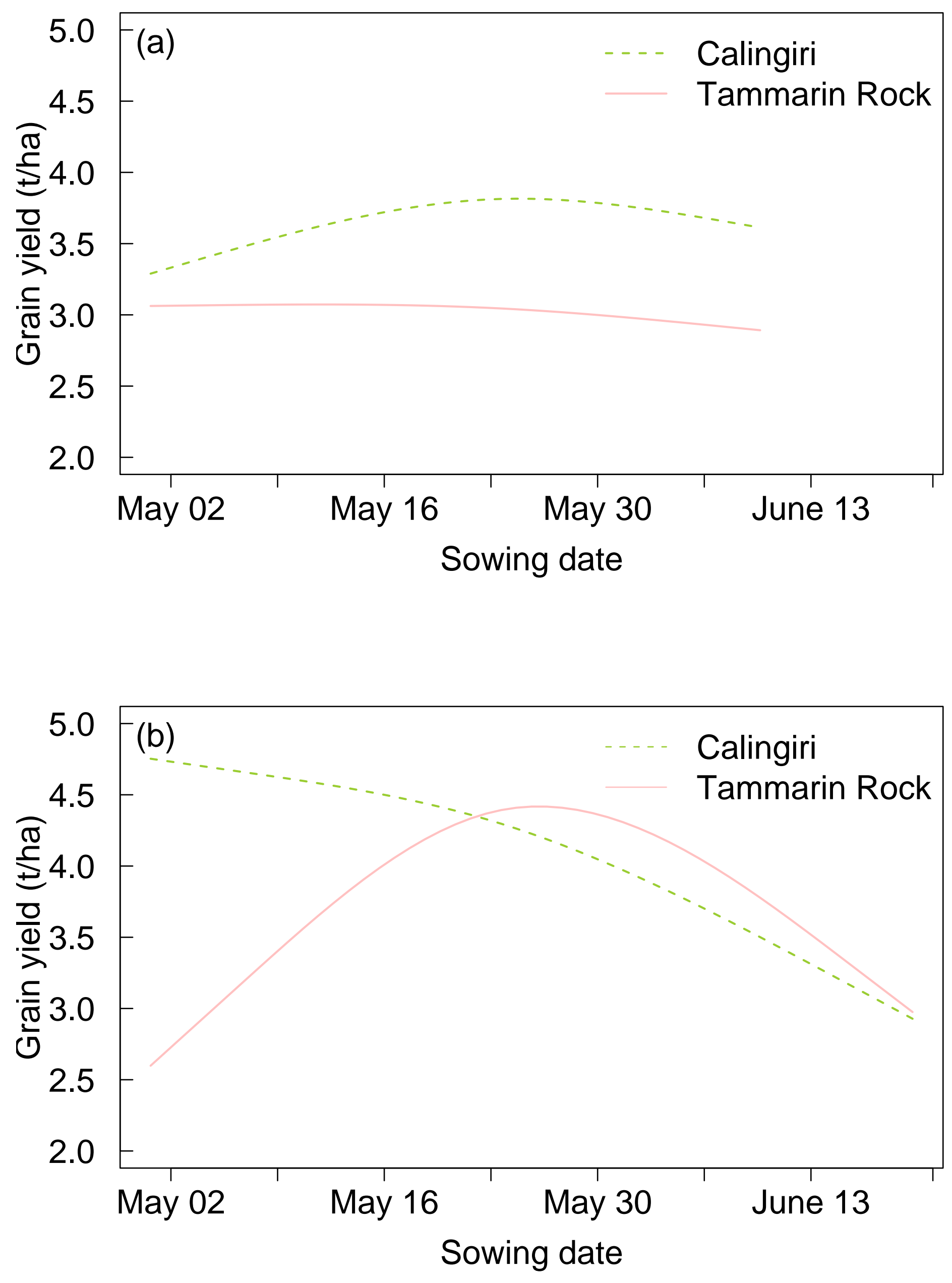


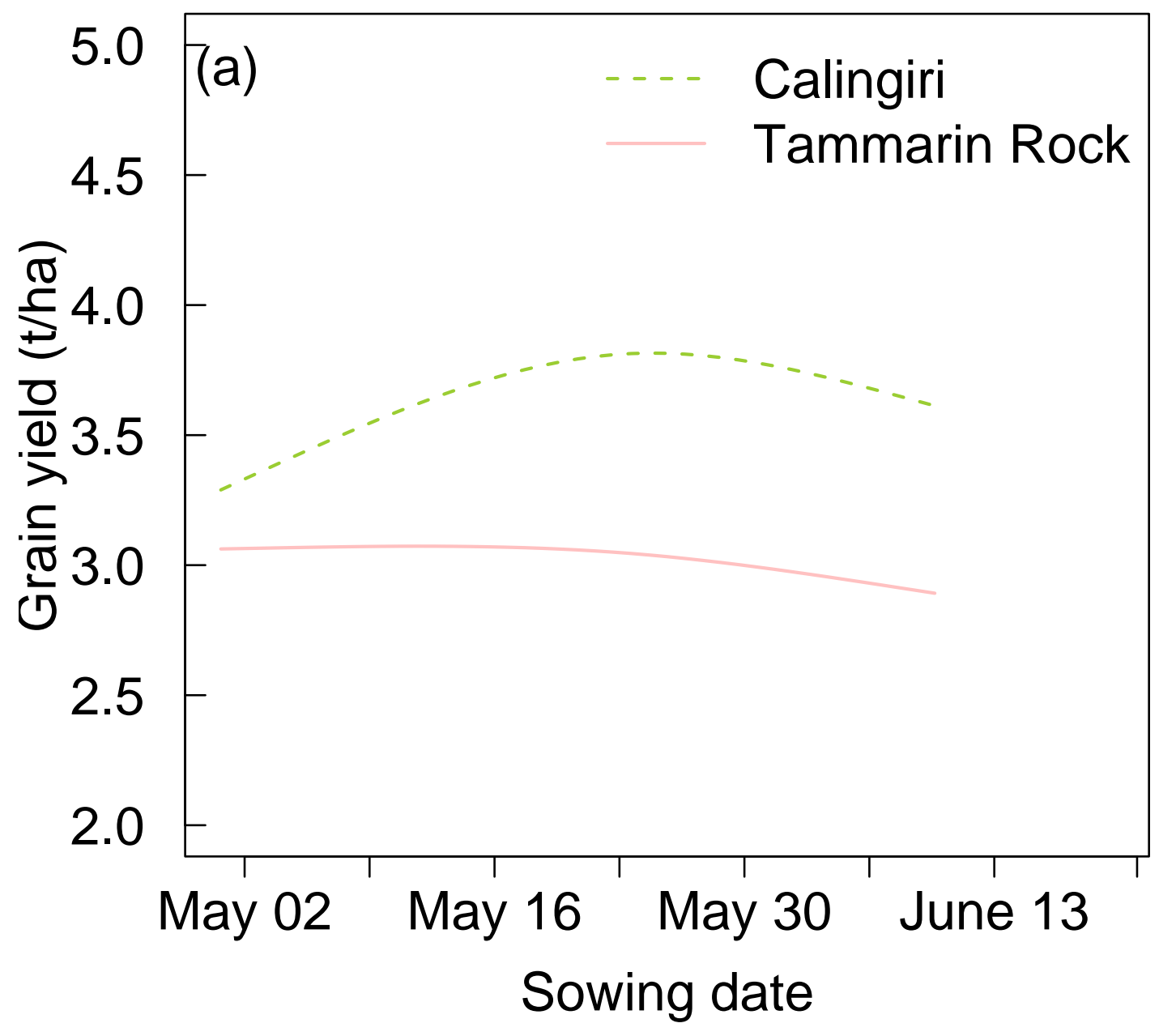




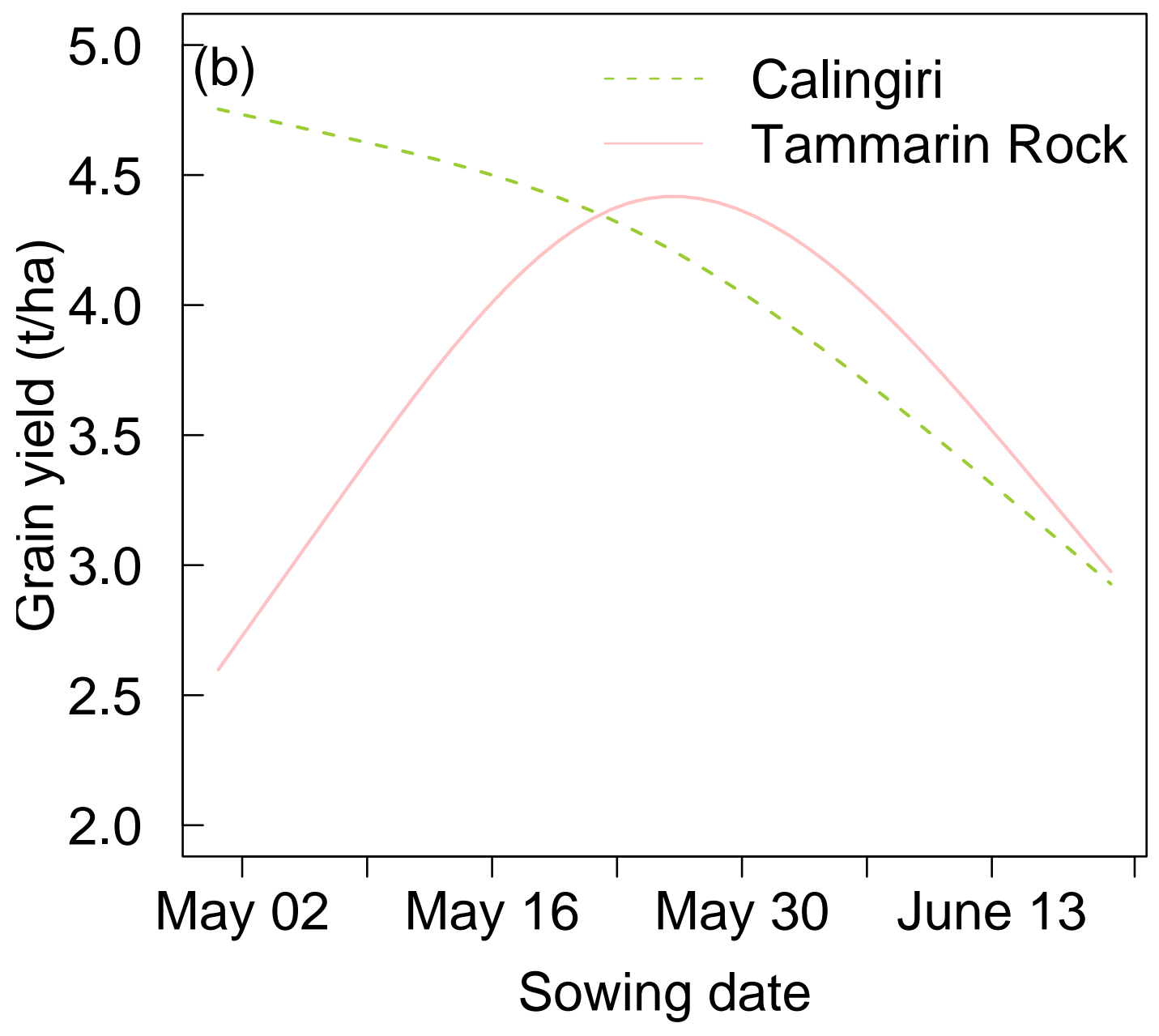




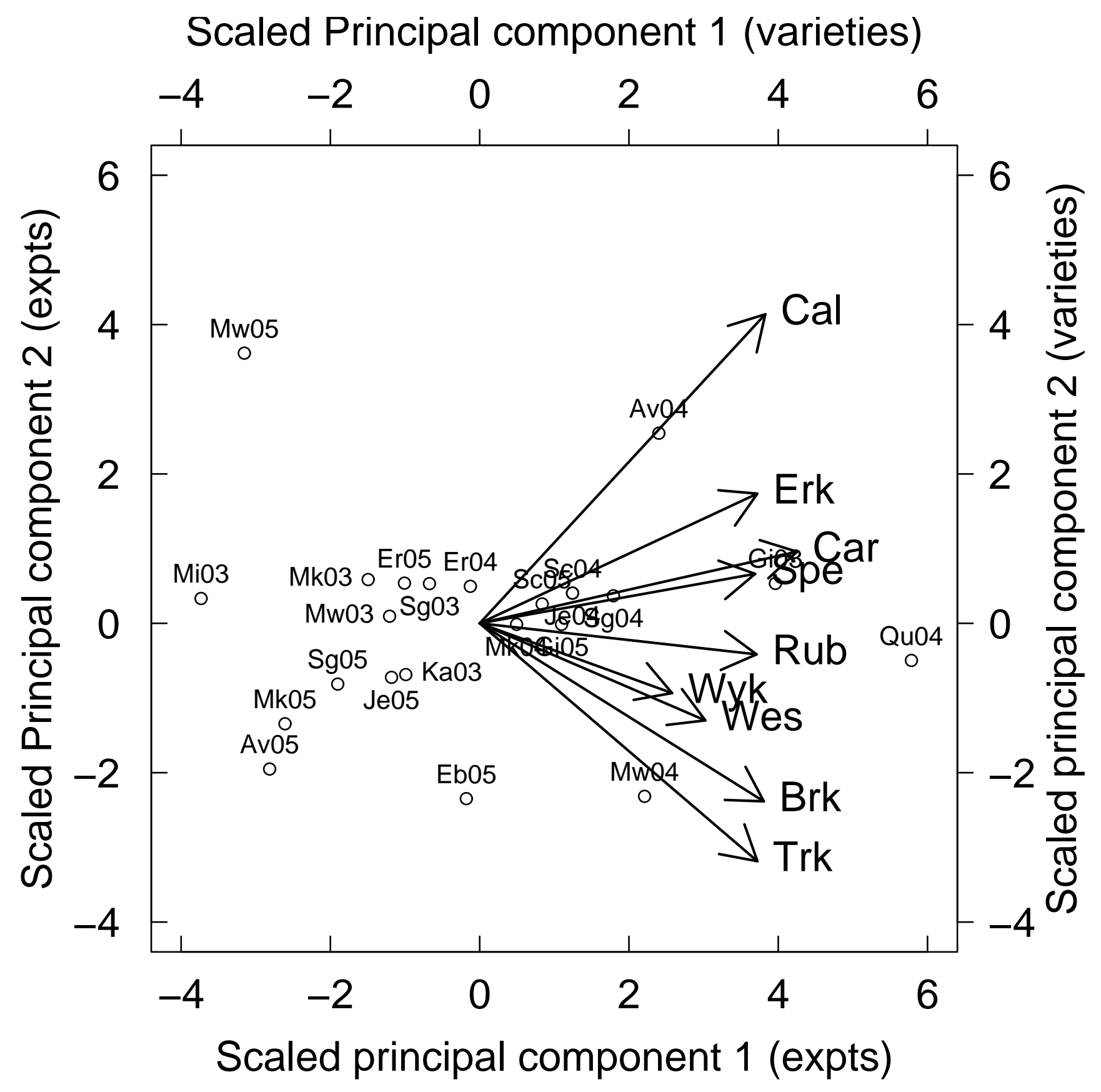




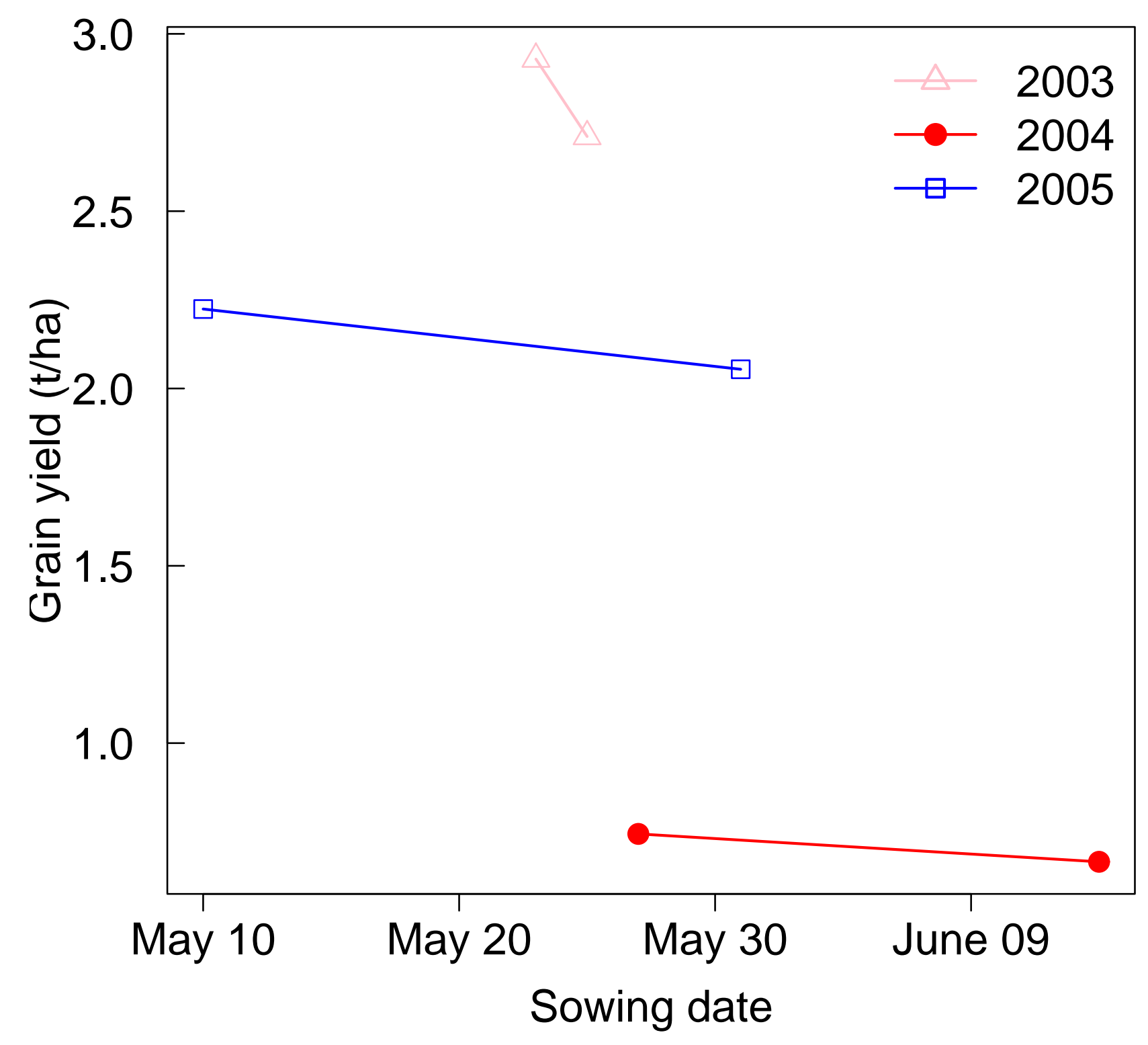




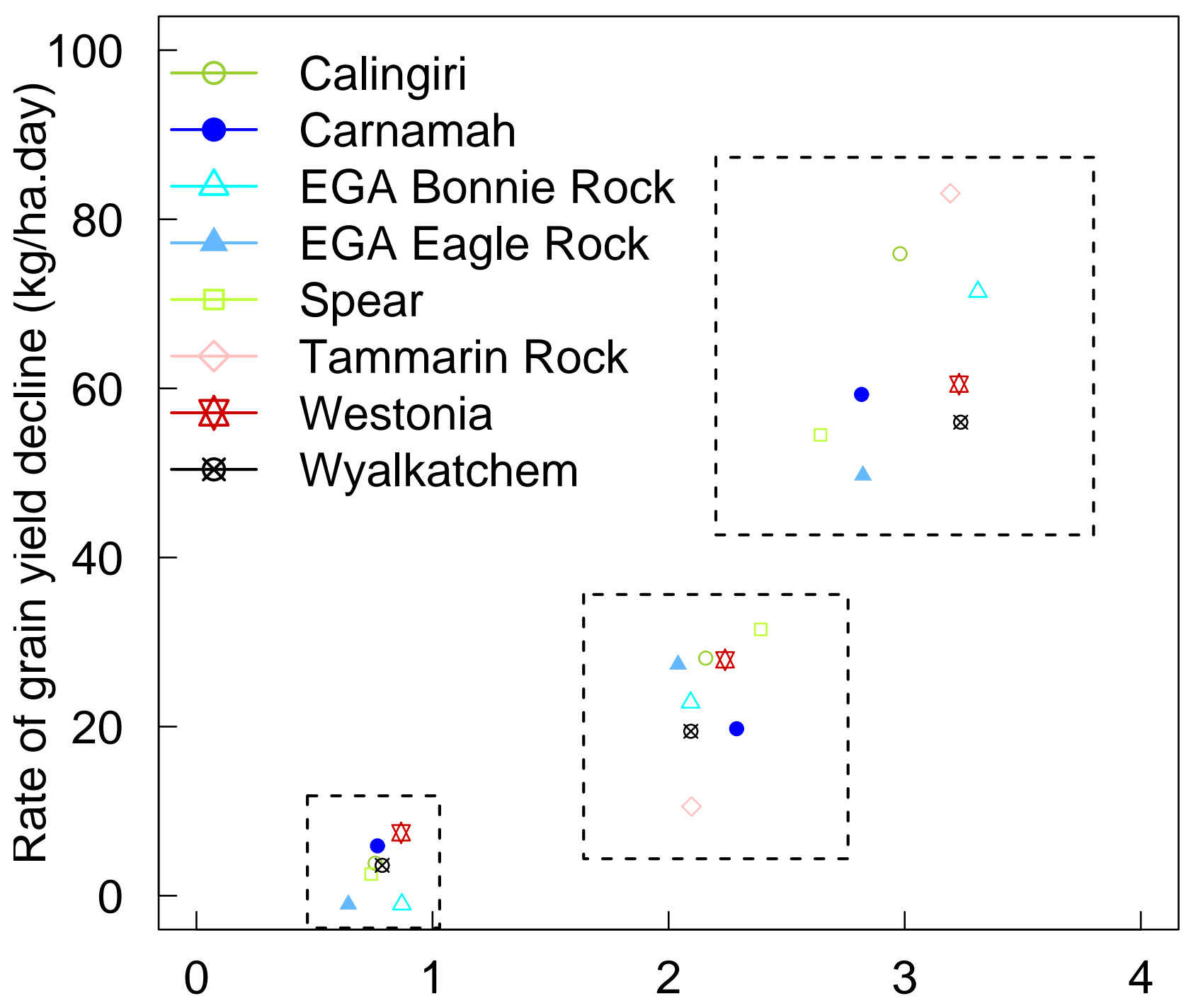

Highest mean grain yield in the respective seasons (t/ha) 


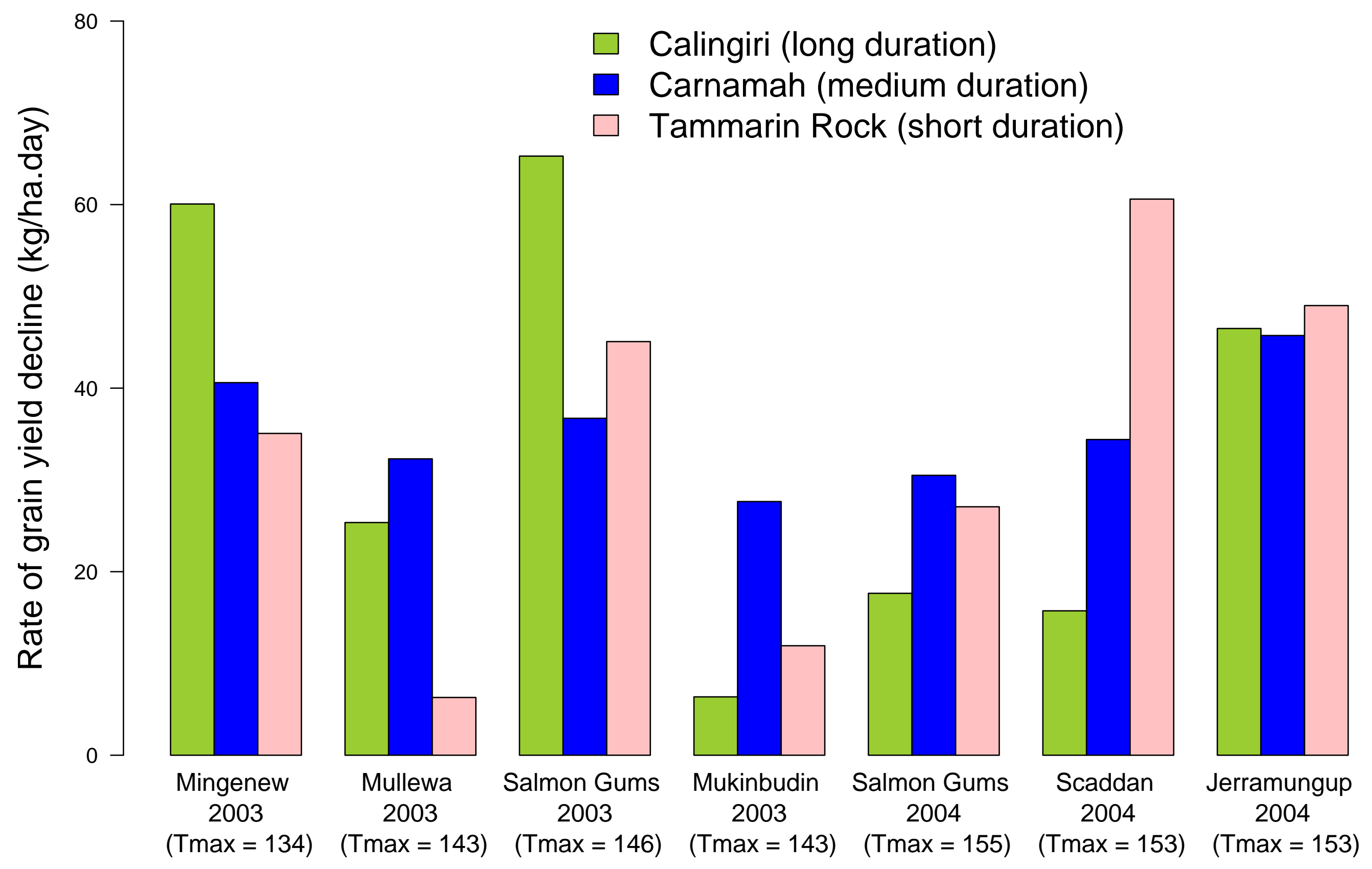




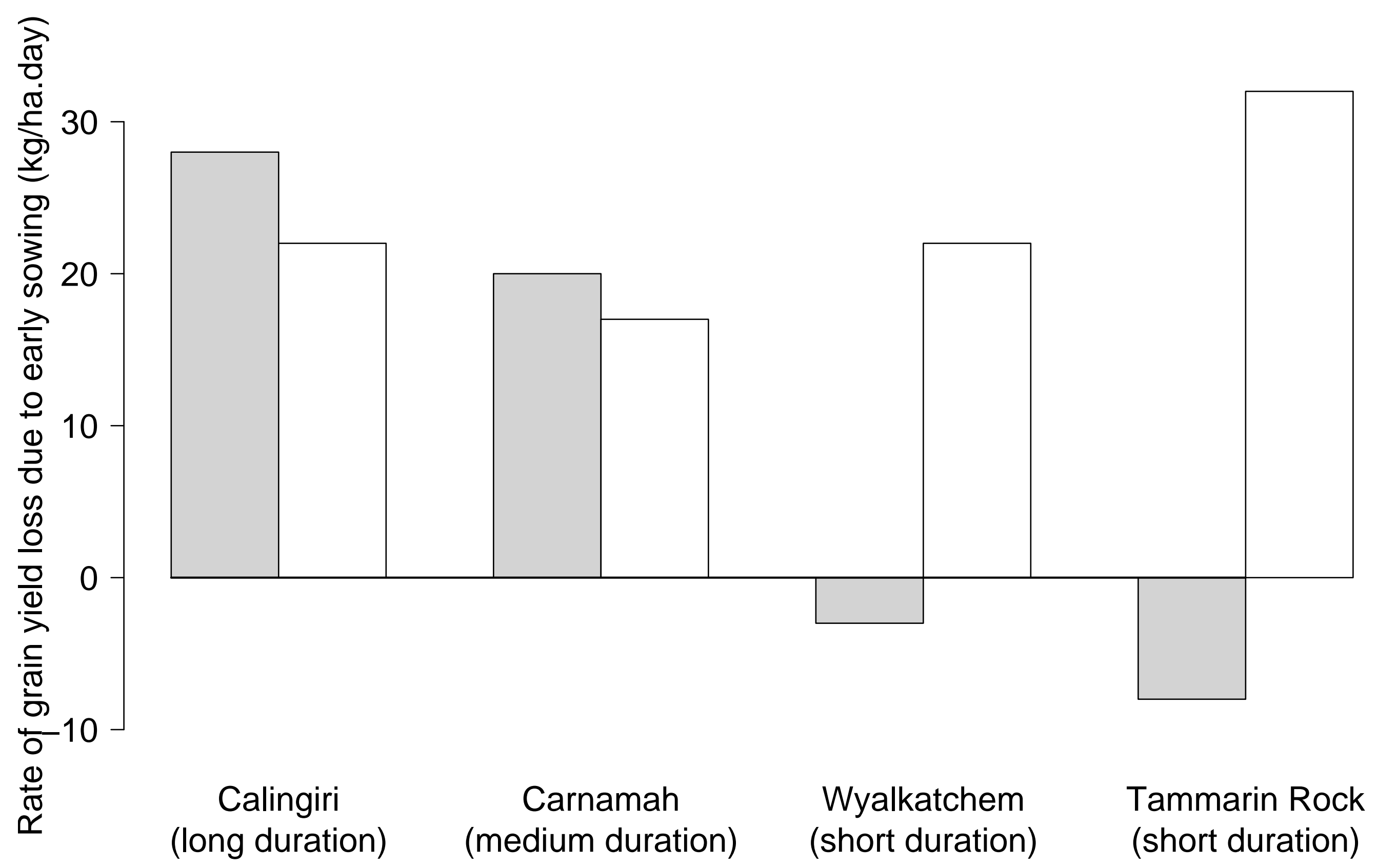




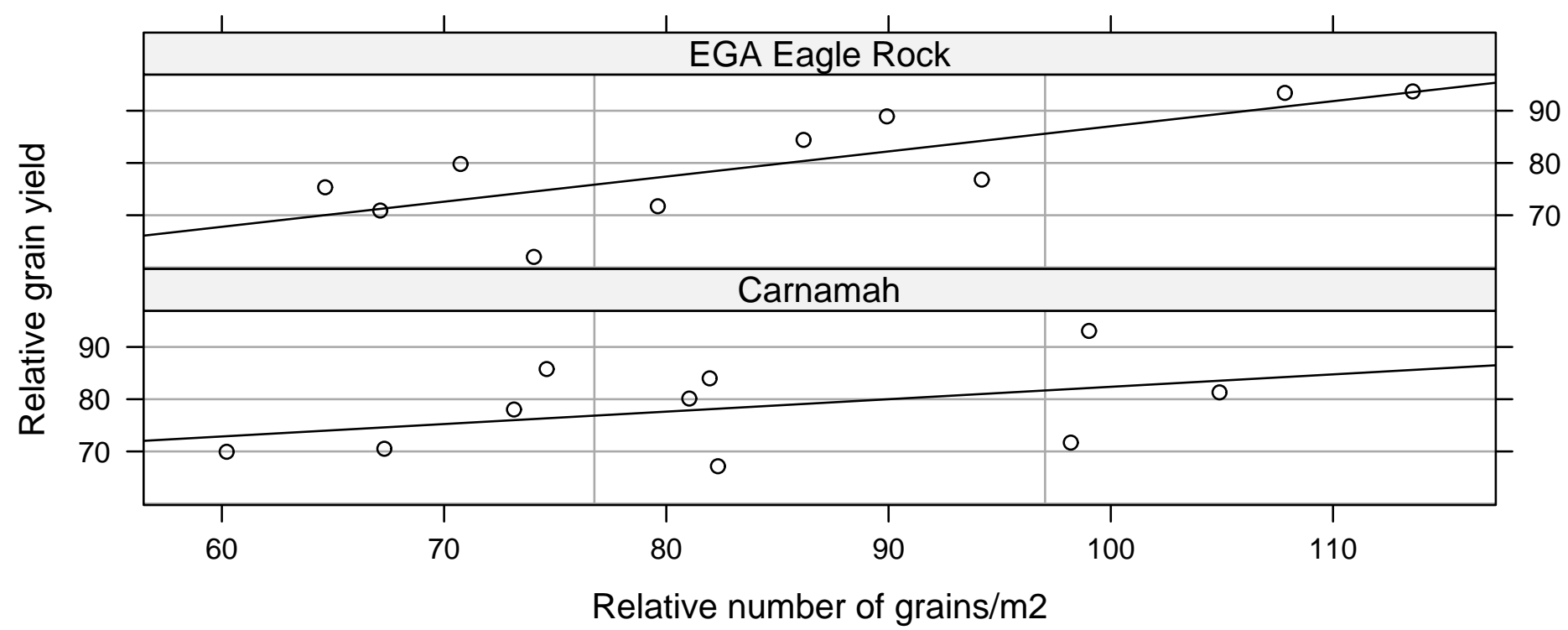

(b)

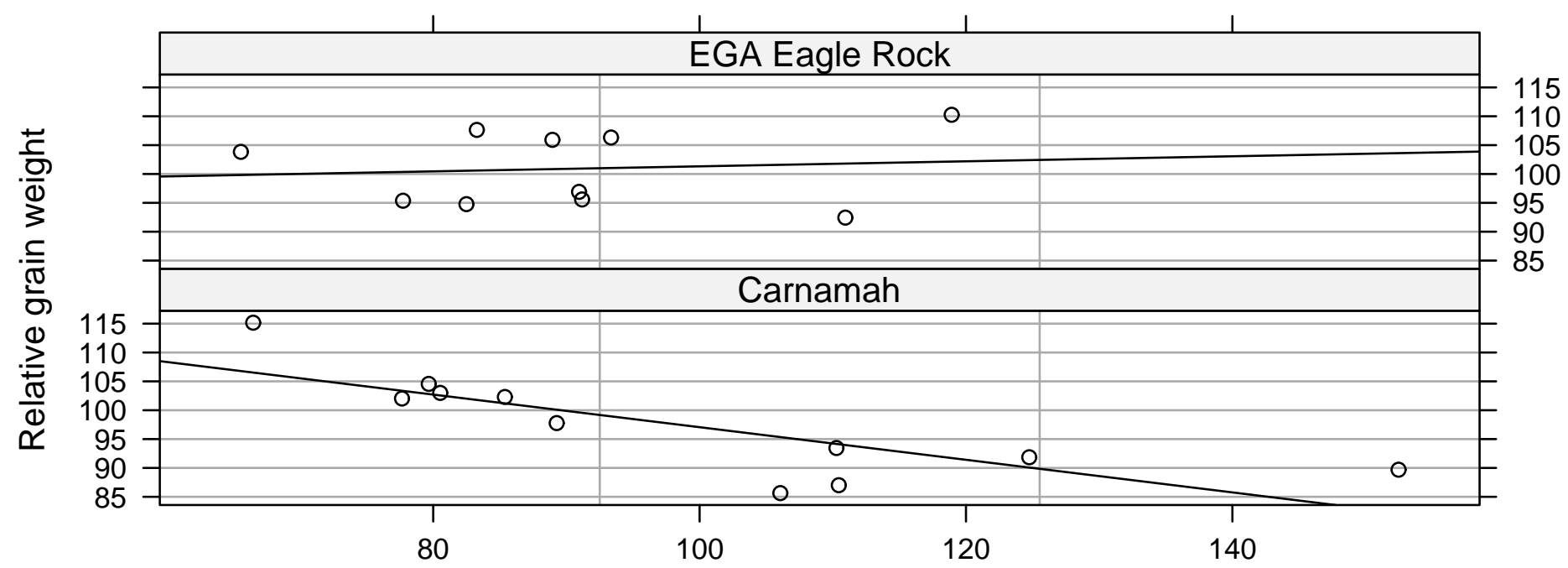

Relative number of grains/spike

(c)

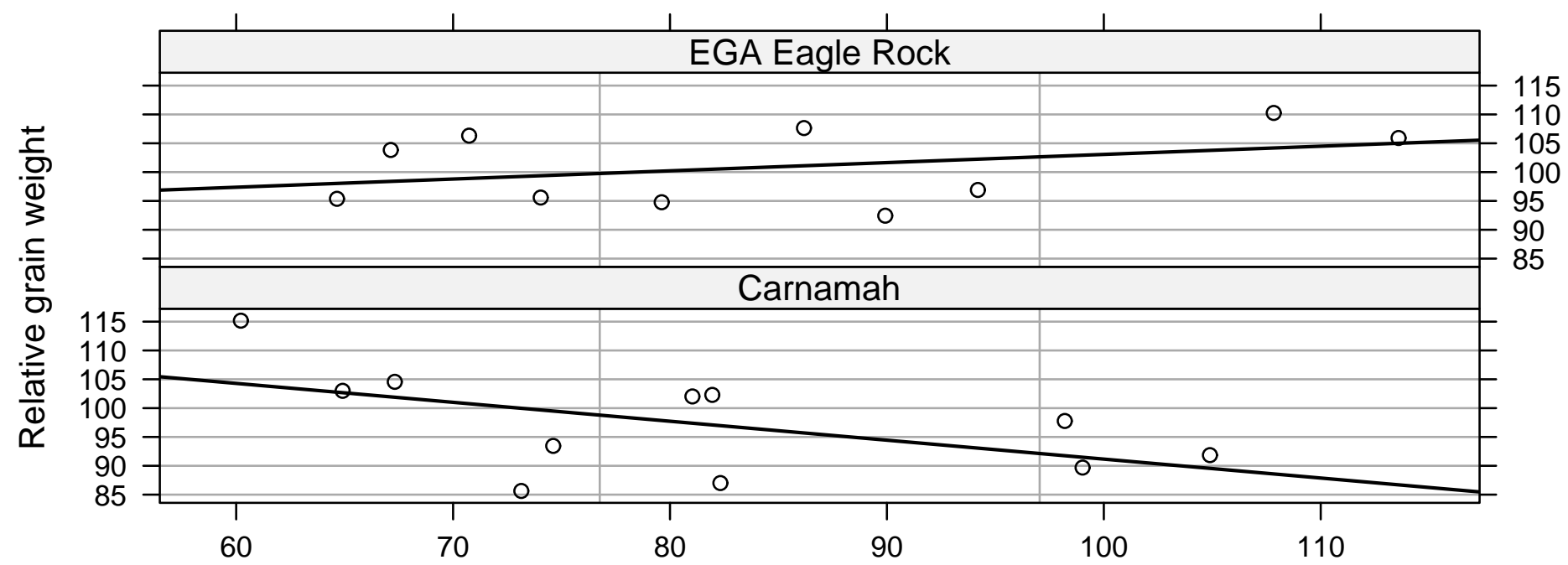

Relative number of grains $/ \mathrm{m} 2$ 
(a)

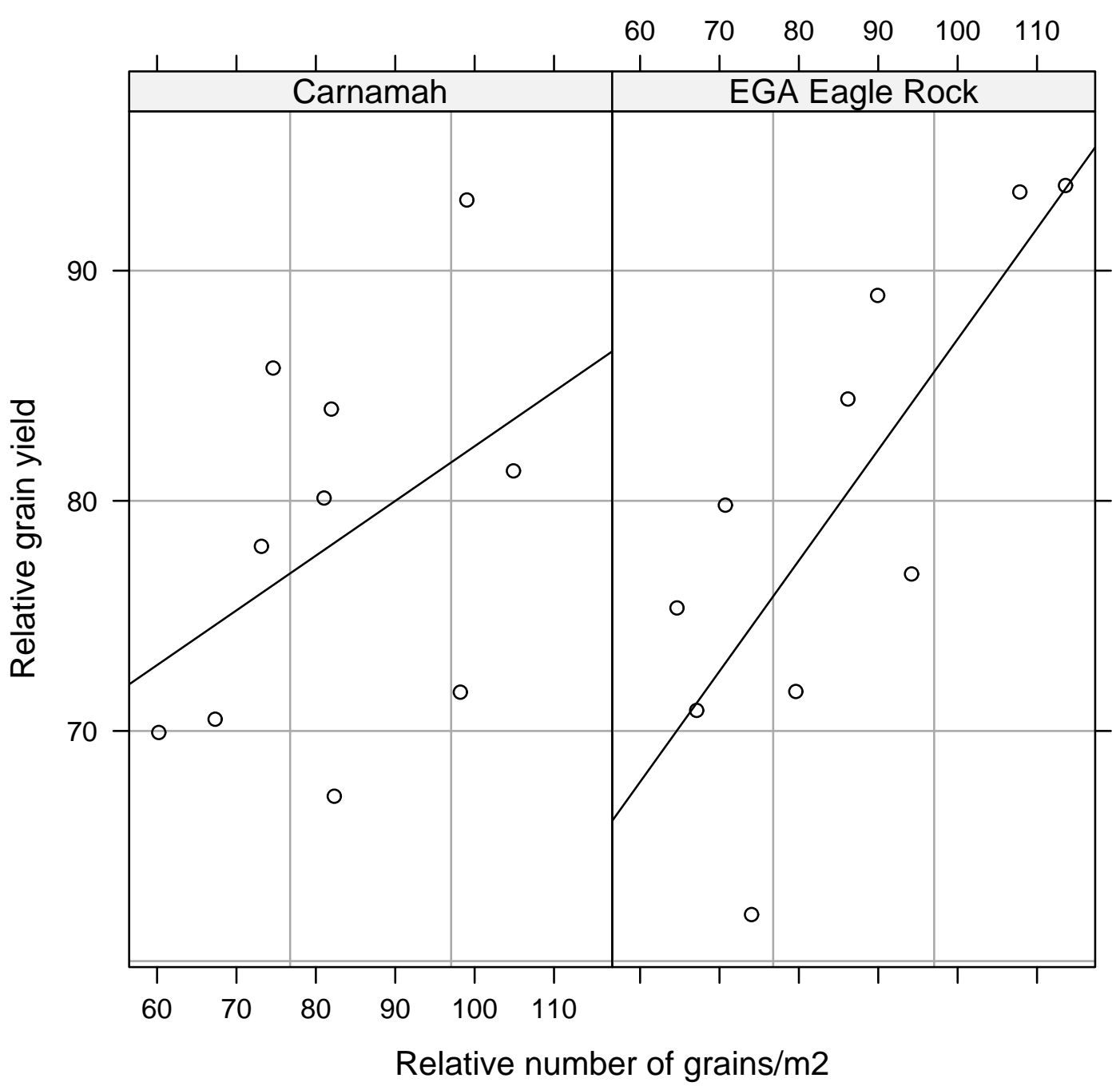


(b)

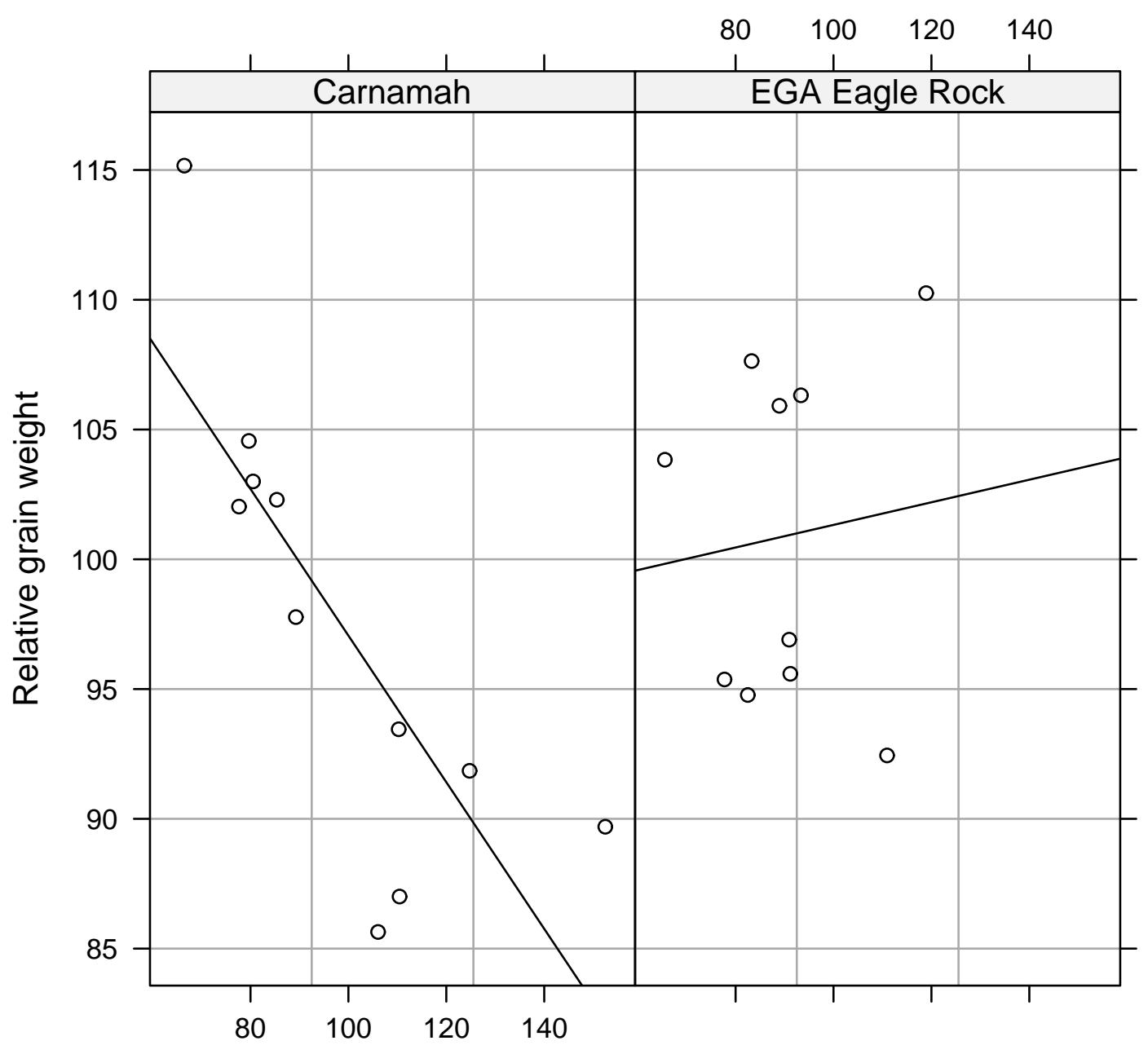

Relative number of grains/spike 
(c)

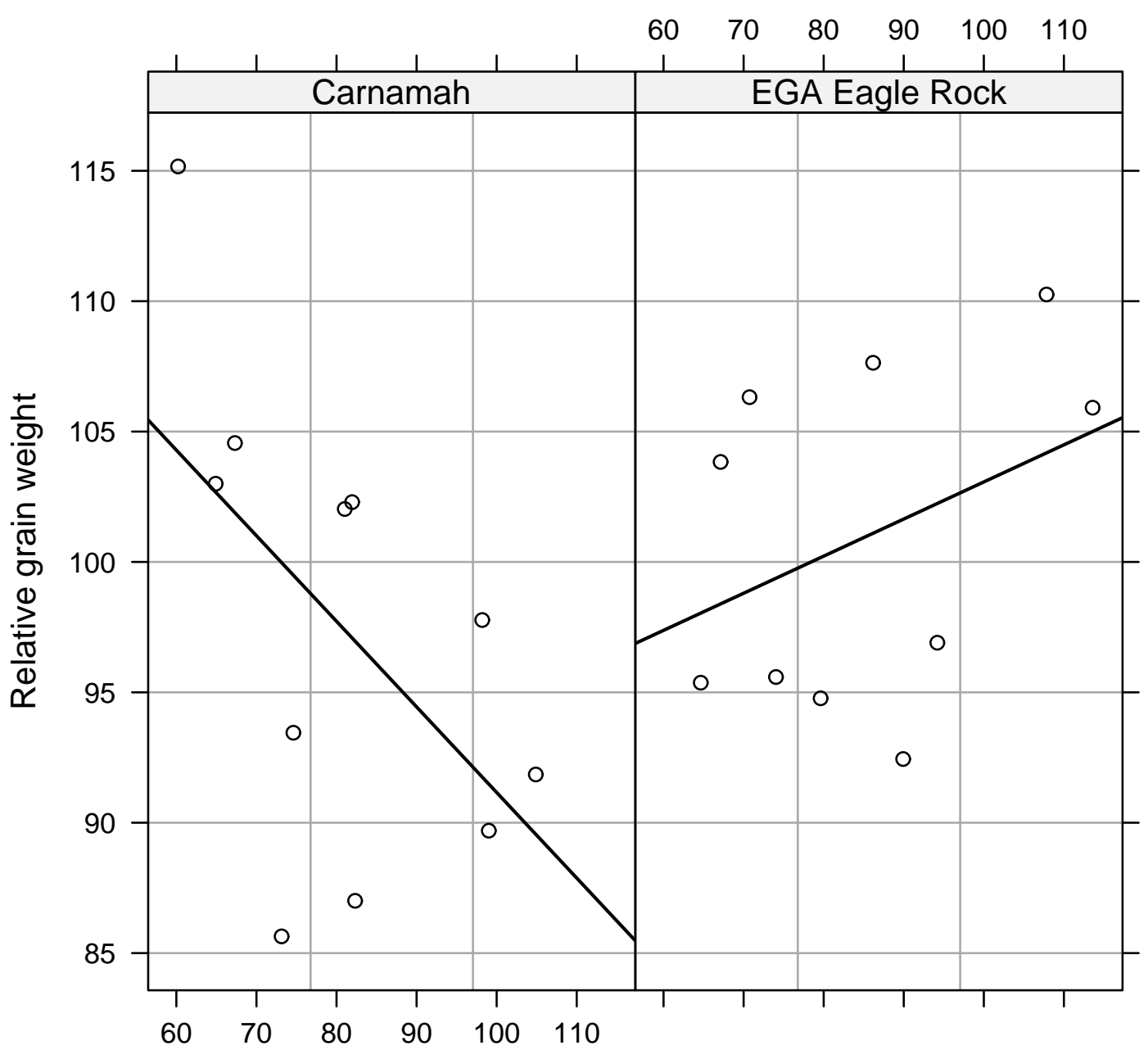

Relative number of grains $/ \mathrm{m} 2$ 